\title{
Measuring ecological preference for growth of the most influential weeds in weed community structure associated with agronomic and horticultural crops in Nile Delta, Egypt
}

Alaa M.M.A. Mahgoub ( $\sim$ alaamahgoub714@gmail.com )

Research article

Keywords: weeds, ecological preference, crop productivity

Posted Date: June 22nd, 2020

DOI: https://doi.org/10.21203/rs.3.rs-30792/v1

License: (c) (1) This work is licensed under a Creative Commons Attribution 4.0 International License. Read Full License 


\section{Abstract}

The studying of the performance of weeds and weed assemblages associated with different crops through phytosociological researches derives its importance mainly from weeds adverse impact on crop productivity. Hopefully, the current study is beneficial for developing a sustainable long term weed control and soil management strategy. The objective of the present work is to measure three ecological preferences: crop diversification, soil type and crop seasonality. A sample area was selected comprising farmland of Nile Delta and its adjoining east and west territories, Egypt. Sixty-four sites in 12 governorates comprising 30 agroecosystems were monitored. 150 species were designated as most influential weed-species out of 555 species recorded. Ecological preference for species for crop seasonality was evident through the results of Agglomerative hierarchical clustering (AHC). Three weed communities or weed assemblages' groups (WAG) were identified. Their diversity evaluated and their linear correlation strength was determined. The fidelity measurements showed that 60 -species have fidelity to WAG A; 46 to WAG B; 44 to WAG C. Measuring the ecological preference of species for crop diversification and soil type indicated that the growth activity of 36-species was more affected by crop diversification; 63-species preferential for growth in fine grained soil (FGS) and 87-species in coarse grained soil (CGS). By employing Redundancy analysis (RDA) with variation partitioning (VP), the variability in species frequency in WAG that can be explained by ecological preference of species for the three ecological preferences was determined and variation was partialized out to estimate their partial, linear effect. In fact, weed control is a recalcitrant issue and the current study revealed that a portion of the solution is in a successful crop diversification plan. The successful selection for a competitive crop that can be taken seriously as an adequate weed controlling mechanism in a crop rotation technique will cause the strongest population reduction of harmful weeds on infested farmland, especially in relevance for crops grown for organic certification.

\section{Background}

The studying of the performance of weeds and weed assemblages associated with different crops through phytosociological researches derives its importance mainly from weeds adverse impact on crop productivity. The adverse impact of weeds on crop productivity was a matter of discussion in weed science researches(Ryan et al., 2009 and Torun \& Uygur, 2018). Several researchers concluded that the harmful effect on crop productivity increased by presence of more invasive species (Thebaud et al., 1996; Reichard \& Hamilton, 1997; Kolar \& Lodge, 2001). Such studies revealed that these invasive species appear to have specific traits or specific combinations of traits that allow them to outcompete not only the native species but the cultivated crops as well. For example, from the common invasive species traits: a higher ecological competence, higher phenotype plasticity, faster growth, more dispersal ability, faster renewal capability after local fire regimens, ...etc. The extent of persistence and resistance of these weeds against weed control plans as in the case of other weeds depend mainly on the genetically inherited characters and the mutations and gene flow which contribute to genetic variability and provide resistant alleles (Mahgoub, 2019a). The harmful effect of weeds on crop yield and the increase of food 
requirements encouraged ecologists to pay further attention and produce more researches. Several models describing the relationship between weed abundance and crop yield were produced, they have been useful for predicting yield loss and assisting with developing management guidelines (Zimdahl, 2004). That coincided with the production of "weed abundance and crop performance models" which have also been useful for characterising the effects of weeds on crop yields under different management systems. This approach allows researchers to evaluate the effectiveness of suites of tactics applied together (Bastiaans et al., 2008). In addition, more advanced simulation models based on weed-crop competition relationships were developed and have further assisted management and research (Bastiaans et al., 1997; Van Ittersum et al., 2003; Nesser et al., 2004). For such programs to be visible, accurate information on the weed flora and the distribution, frequency, abundance and phenology of weed species and weed communities are prerequisite (Frick and Thomas, 1992; Ghersa and Holt, 1995). Such kind of data may also be valuable for understanding weed communities and for creating a higher biodiversity in arable land (Andreasen and Skovgaard, 2009). Despite that weed assemblages associated with either agronomic or horticultural crops was a subject of study in several phytosociological researches (Amer et al., 1990; Menalled et al., 2001; Mashaly et al., 2002, 2010; Shaltout et al., 2015; Ahmad Z. et al., 2016; Begum et al., 2016 and Mahgoub, 2017, 2019 a, 2019 b), however, the objective of this work was not adequately addressed. The present study aimed to measure ecological preference for growth of the most influential weeds in weed community structure associated with agronomic and horticultural crops in Nile Delta, Egypt. Hopefully that is beneficial to help for the development of a sustainable long term weed control and soil management strategy.

A sample area was selected comprising farmland of Nile Delta and its adjoining east and west territories, Egypt. The delta is the major constituent of the farmed lands of Egypt and the governmental reports indicated that $\approx 61 \%$ of the priority reclaimable land through the Nile waters is located on the fringes of the Delta region where soil, in parts of these areas, is loamy in nature; cultivation can be relatively successful (Biswas, 1993). Three ecological preferences which represent the main drivers for weed growth were selected: crop seasonality, crop diversification and soil type. No one denies the importance of crop seasonality as one of the main drivers affecting weed community structure. Through phytosociological researches, ecologists concluded that seasonality is an evident feature of weed plant growth, as it is equally evident in cropping rotation (Mahgoub, 2017, 2019a) and a crop rotation is accompanied by a weed-flora rotation (El Hadidi \& Kosinová, 1971). The cultivation of non-traditional crops throughout crop diversification, especially in reclaimed land, has become one of the means of improving agricultural economic policy in many countries, including Egypt. The European Conference on Crop Diversification in 2019 reflects the importance of this concept. Hence, it is worth to questionnaire about the preference of weeds for growth in response for this ecological preference. The effect of soil type and properties on vegetation structure was explicit through several phytosociological researches. From different environmental factors, soil properties are of prime importance as they directly influence plant growth and distribution (Hoveizeh, 1997). In his phytosociological study on the vegetation structure in Isthmus of Suez and adjoining farmland east Nile delta, Mahgoub (2019b) concluded that the variation of plant species composition and weed community structure was strongly spatially structured by soil 
type and properties. It is often that ecologists use multivariate analysis and ordination techniques to describe the relationship between a set of samples based on their attributes (Streibig, 1979; Salonen, 1993; Andersson \& Milberg, 1998; Anderson, 2001, 2006 and Clarke \& Warwick, 2001a) and in the current study, both multivariate analyses and ordination techniques employed.

\section{Full Text}

\section{Measuring ecological preference for growth of the most influential weeds in weed community structure associated with agronomic and horticultural crops in Nile Delta, Egypt}

\section{ALAA M. M. A. MAHGOUB}

\section{Independent researcher}

\section{(Former affiliation, Lecturer in Department of Botany, Faculty of Science, Cairo University, Giza, Egypt)}

Abstract:The studying of the performance of weeds and weed assemblages associated with different crops through phytosociological researches derives its importance mainly from weeds adverse impact on crop productivity. Hopefully, the current study is beneficial for developing a sustainable long term weed control and soil management strategy. The objective of the present work is to measure three ecological preferences: crop diversification, soil type and crop seasonality. A sample area was selected comprising farmland of Nile Delta and its adjoining east and west territories, Egypt. Sixty-four sites in 12 governorates comprising 30 agroecosystems were monitored. 150 species were designated as most influential weed-species out of 555 species recorded. Ecological preference for species for crop seasonality was evident through the results of Agglomerative hierarchical clustering (AHC). Three weed communities or weed assemblages' groups (WAG) were identified. Their diversity evaluated and their linear correlation strength was determined. The fidelity measurements showed that 60 -species have fidelity to WAG A; 46 to WAG B; 44 to WAG C. Measuring the ecological preference of species for crop diversification and soil type indicated that the growth activity of 36-species was more affected by crop diversification; 63-species preferential for growth in fine grained soil (FGS) and 87-species in coarse grained soil (CGS). By employing Redundancy analysis (RDA) with variation partitioning (VP), the variability in species frequency in WAG that can be explained by ecological preference of species for the three ecological preferences was determined and variation was partialized out to estimate their partial, linear effect. In fact, weed control is a recalcitrant issue and the current study revealed that a portion of the solution is in a successful crop diversification plan. The successful selection for a competitive crop that can be taken seriously as an adequate weed controlling mechanism in a crop rotation technique will 
cause the strongest population reduction of harmful weeds on infested farmland, especially in relevance for crops grown for organic certification.

\section{Corresponding author: alaamahgoub714@gmail.com}

- Introduction

The studying of the performance of weeds and weed assemblages associated with different crops through phytosociological researches derives its importance mainly from weeds adverse impact on crop productivity. The adverse impact of weeds on crop productivity was a matter of discussion in weed science researches(Ryan et al., 2009 and Torun \& Uygur, 2018). Several researchers concluded that the harmful effect on crop productivity increased by presence of more invasive species (Thebaud et al., 1996; Reichard \& Hamilton, 1997; Kolar \& Lodge, 2001). Such studies revealed that these invasive species appear to have specific traits or specific combinations of traits that allow them to outcompete not only the native species but the cultivated crops as well. For example, from the common invasive species traits: a higher ecological competence, higher phenotype plasticity, faster growth, more dispersal ability, faster renewal capability after local fire regimens, ...etc. The extent of persistence and resistance of these weeds against weed control plans as in the case of other weeds depend mainly on the genetically inherited characters and the mutations and gene flow which contribute to genetic variability and provide resistant alleles (Mahgoub, 2019a). The harmful effect of weeds on crop yield and the increase of food requirements encouraged ecologists to pay further attention and produce more researches. Several models describing the relationship between weed abundance and crop yield were produced, they have been useful for predicting yield loss and assisting with developing management guidelines (Zimdahl, 2004). That coincided with the production of "weed abundance and crop performance models" which have also been useful for characterising the effects of weeds on crop yields under different management systems. This approach allows researchers to evaluate the effectiveness of suites of tactics applied together (Bastiaans et al., 2008). In addition, more advanced simulation models based on weed-crop competition relationships were developed and have further assisted management and research (Bastiaans et al., 1997; Van Ittersum et al., 2003; Nesser et al., 2004). For such programs to be visible, accurate information on the weed flora and the distribution, frequency, abundance and phenology of weed species and weed communities are prerequisite (Frick and Thomas, 1992; Ghersa and Holt, 1995). Such kind of data may also be valuable for understanding weed communities and for creating a higher biodiversity in arable land (Andreasen and Skovgaard, 2009). Despite that weed assemblages associated with either agronomic or horticultural crops was a subject of study in several phytosociological researches (Amer et al., 1990; Menalled et al., 2001; Mashaly et al., 2002, 2010; Shaltout et al., 2015; Ahmad Z. et al., 2016; Begum et al., 2016 and Mahgoub, 2017, 2019 a, 2019 b), however, the objective of this work was not adequately addressed. The present study aimed to measure ecological preference for growth of the most influential weeds in weed community structure associated with agronomic and horticultural crops in Nile Delta, Egypt. Hopefully that is beneficial to help for the development of a sustainable long term weed control and soil management strategy. 
A sample area was selected comprising farmland of Nile Delta and its adjoining east and west territories, Egypt. The delta is the major constituent of the farmed lands of Egypt and the governmental reports indicated that $\approx 61 \%$ of the priority reclaimable land through the Nile waters is located on the fringes of the Delta region where soil, in parts of these areas, is loamy in nature; cultivation can be relatively successful (Biswas, 1993). Three ecological preferences which represent the main drivers for weed growth were selected: crop seasonality, crop diversification and soil type. No one denies the importance of crop seasonality as one of the main drivers affecting weed community structure. Through phytosociological researches, ecologists concluded that seasonality is an evident feature of weed plant growth, as it is equally evident in cropping rotation (Mahgoub, 2017, 2019a) and a crop rotation is accompanied by a weed-flora rotation (El Hadidi \& Kosinová, 1971). The cultivation of non-traditional crops throughout crop diversification, especially in reclaimed land, has become one of the means of improving agricultural economic policy in many countries, including Egypt. The European Conference on Crop Diversification in 2019 reflects the importance of this concept. Hence, it is worth to questionnaire about the preference of weeds for growth in response for this ecological preference. The effect of soil type and properties on vegetation structure was explicit through several phytosociological researches. From different environmental factors, soil properties are of prime importance as they directly influence plant growth and distribution (Hoveizeh, 1997). In his phytosociological study on the vegetation structure in Isthmus of Suez and adjoining farmland east Nile delta, Mahgoub (2019b) concluded that the variation of plant species composition and weed community structure was strongly spatially structured by soil type and properties. It is often that ecologists use multivariate analysis and ordination techniques to describe the relationship between a set of samples based on their attributes (Streibig, 1979; Salonen, 1993; Andersson \& Milberg, 1998; Anderson, 2001, 2006 and Clarke \& Warwick, 2001a) and in the current study, both multivariate analyses and ordination techniques employed.

- Methodology

\subsection{The study area}

Geography: The area of study is teardrop shaped (C. $\approx 27,231 \mathrm{Km}^{2}\left(10,514 \mathrm{mi}^{2}\right)$, Figure 1). It comprised farmland of Nile Delta and adjoining east and west territories. The Nile Delta is one of the world's largest river deltas and is a rich agricultural region. The base of the Nile Delta represents the northern side of the study area, it covers some $240 \mathrm{~km}(150 \mathrm{mi})$ of Mediterranean coastline, from Alexandria in the west (coordinates: $31^{\circ} 12^{\prime} 27.3^{\prime \prime} \mathrm{N}, 2^{\circ} 55^{\prime} 09.0^{\prime \prime} \mathrm{E}$; Latitude: 31.207592 , Longitude: 29.919168 ) to Port Said in the east ( $31^{\circ} 16^{\prime} 09.6^{\prime \prime} \mathrm{N}, 32^{\circ} 18^{\prime} 04.1^{\prime \prime} \mathrm{E}$; Lat, Long: $\left.31.269344,32.301133\right)$. From north to south the delta is approximately $160 \mathrm{~km}(99 \mathrm{mi})$ in length, from Baltim (31 $33^{\prime} 19.7^{\prime \prime} \mathrm{N}, 31^{\circ} 05^{\prime} 45.3^{\prime \prime} \mathrm{E}$; Lat, Long: 31.555461 , $31.095909)$ to Cairo $\left(30^{\circ} 02^{\prime} 40.9^{\prime \prime} \mathrm{N}, 31^{\circ} 14^{\prime} 07.3^{\prime \prime} \mathrm{E}\right.$; Lat, Long: $\left.30.044698,31.235365\right)$. The Suez Canal borders the study area from the east and the Western Desert from the west. The sample area comprises several types of ecological habitats: fertile lands of the Nile Delta; farmland facing the Nile including those of the Delta and its adjoining east and west territories; farmland at the fringes of salt marshes; 
those facing Mediterranean Sea; nearby the littoral sand dunes and reclaimed land in west-delta region and near to the western desert in west side, and at Isthmus of Suez and east-delta region in east side.

Climate: The Meteorological records of the area were obtained as a courtesy from the Egyptian Meteorological Authority "EMA", they include the records of the monthly averages of rainfall $(\mathrm{mm})$, temperature $\left({ }^{\circ} \mathrm{C}\right)$, relative humidity and evaporation from 1931 to 2017 . The records revealed that from $100-200 \mathrm{~mm}$ (4-8 in) of rain falls on the delta area during an average year, and most of these falls in the winter months. The northernmost part is the wettest region of the sample area. With the onset of the winter season, at the end of October through the beginning of May, the northwestern delta area is exposed to 21 squalls. They are usually accompanied with lightning thunderstorms, low temperature, high wind speeds, and cloud bursts, which produce heavy rain showers. The Delta has relatively moderate temperatures, with highs usually not surpassing $31^{\circ} \mathrm{C}\left(88^{\circ} \mathrm{F}\right)$ in the summer. The area experiences its hottest temperatures in July and August, with a maximum average of $34^{\circ} \mathrm{C}\left(93^{\circ} \mathrm{F}\right)$. Winter temperatures are normally in the range of $9{ }^{\circ} \mathrm{C}\left(48^{\circ} \mathrm{F}\right)$ at nights to $19^{\circ} \mathrm{C}\left(66^{\circ} \mathrm{F}\right)$ in the daytime. Minimum temperature records usually don't seem to reach freezing. With cooler temperatures and some rain, the Nile Delta region becomes quite humid during the winter months, but the records of the southern meteorological stations for its adjoining east and west territories, away from the water bodies of the Mediterranean, were an express of drier atmosphere and higher rates of evaporation.

Soil type: According to the geological map of Egypt (ESDAC, 2017) and other geological researches (Elbasiouny \& Elbehiry, 2019 and Said, 1962), the following Quaternary formations were identified in the Nile Delta: recent Nile alluvium (Nile deposits); superficial deposits (sand dunes and sabkha deposits) and undivided quaternary (wadi and playa deposits, and raised beaches). The first formation included cultivated fertile land of Nile Delta and the other two included reclaimed land in the north, east and west territories of the study area. The surface of the Delta in the south is relatively smooth if compared to its surface in the north (Abu AL-Izz, 1977). Soils of the Nile Delta are mostly heavy in the texture and rather compact at the surface and the humus status of the soils is fairly well (EL-GABALY et al., 1969). Thus, all soils with exception of the northernmost part, are manmade and are regarded as anthropogenic variants of the Gleysols and Fluvisols (Shaltout et al., 1992). The chemical and mechanical analyses for the sites and localities of the study area were quoted from those recorded by the Ministry of Agriculture and Land Reclamation (MALR), Department of soil survey, Egypt, for respect of its authority and farmers property. The depth of soil horizon profiles were $0-30,30-60,60-90,90-120 \mathrm{~cm}$., in them the following soil properties were measured: 1) soil texture expressed as percentage for clay, silt, clay + silt, fine sand, coarse sand, 2) Water holding capacity (100 gm soil \%), 3) Hydrolytic conductivity (cm./hour), 4) Soil reaction (PH), 5) Main salts in water saturated soil extract: for cations ( $\mathrm{Ca}, \mathrm{Mg}, \mathrm{Na}, \mathrm{K})$, and for anions $(\mathrm{CO} 3, \mathrm{HCO} 3, \mathrm{Cl}), 6)$ Total soluble salts (\%) and 7) Calcium carbonate content (CaCO3). The results of these analyses revealed that a soil type may dominate a sampling site (district), though another sampling site may comprise one or sometimes several soil types. Accordingly, the weight average was calculated to express the soil properties that dominate a certain area. 
The surveyed sampling sites were clustered into two basic classes of soil type based on texture and a simple particle-size analysis according to USCS (The Unified Soil Classification System, ASTM International). The ecological preference for weed growth was rated according to soil texture from fine to coarse. Thus, the ecological preference of weed growth was measured in two basic soil types: Coarsegrained soils (CGS) which contain 50 percent or less of fines (including gravel soil and sandy soil), and Fine-grained soils (FGS) which contain more than 50 percent fines (silt and clay). Accordingly, out of the 64 sites surveyed a total of 40 sites were designated FGS and 24 sites CGS.

\subsection{Field sampling design and data collection}

Stratified sampling technique (Müller-Dombois \& Ellenberg, 1974: pp. 177-209) was used as an ecological sampling design method. A total of 64 georeferenced sampling sites were located randomly in 12 governorates, in the Nile Delta and its adjoining east and west territories to represent 30 agroecosystems which were defined at the level of cultivated crops (agronomic and horticultural crops) in the different ecological habitats (refer to Figure 1). In each sampling site, field plots (relevés) for the cultivated crops were surveyed, each of which 1000-1500 $\mathrm{m}^{2}$. Field plots were visited and the species were recorded in the different seasons through sequential seasonal excursions during 2018. Three visits during the winter half of the year from December to May (in January, March, and April) and the other three visits in the summer half of the year from June to November (in June, August, and September). The weed assemblages associated with the cultivated crops were recorded and the presence of species was taken to indicate degree of ecological success and sociological performance. Presence estimate percentage $\mathrm{PE} \%$ for species in each crop was calculated in the raw data set. One hundred and fifty species were categorized as "the most influential weed species" in the weed community structure associated with agricultural and horticultural crops out of the 555 species recorded. These weeds had PE\% $\geq 30 \%$ in at least in one of the agroecosystems monitored. The values of PE\% were calculated as an average from species records: in March \& April for the eight winter crops; in August \& September for the six summer crops; in August for the two melon crops and the highest average of their PE\% values for the two records groups of March-April and of August-September for perennial and orchard crops. For those weed species which are not included in these records but monitored in other months, their highest PE \% record was accepted in these months. The monitored crops were traditionally classified according to their season (period through which the crop occupies the field) and their position in the yearly agricultural rotation. Agronomic crops included: eight winter crops (WC): Clover, Wheat, Broad bean, Flax, Potato, Artichoke, Tomato "winter" and Vegetables "winter"; nine summer crops (SC): Cotton, Maize, Rice, Tomato "summer", Peanut, Soybean or Soya bean, Watermelon, Sweet-melon and Vegetables "summer" and two perennial crops (PC): Taro and Sugarcane. Horticultural crops (Orchards (OC)) included eleven genera: Citrus, Guava, Pear, Banana, Mango, Prunus, Apple, Olive, Pomegranate, Date palm and Grape. The first two letters were used as a crop code during analyses and if similar with others, the subsequent ones were used (for crop codes and botanical nomenclature, refer to Appendix 1). Some crops have two types of cultivations, e.g. Tomato plantings which are cultivated as a winter crop in sandy soils and as a summer 
crop in clay and clay loamy soils. It should be also pointed out that several genera monitored in orchards crops (e.g. Citrus and Prunus) included more than one cultivated species, subgenus, or varieties.

The ecological preference of species for soil type, crop seasonality and crop diversification were measured, based on their values of Fr (frequency, Cain, 1959; Bonham, 2013) and Ab (abundance, Preston, 1948; Damgaard, 2009; Verberk, 2011). Given these importance values, one can link the maximum species growth activity with its ecological preferences for a certain soil type in a certain crop type.

The comparison of species importance values ( $\mathrm{Fr}$ and $\mathrm{Ab}$ ) measured in crops cultivated in fine grain soils sites (FGS) with those measured in coarse grain soils sites (CGS), was taken as an express of the ecological preference of species for soil type. Indicator value of species (IndVal) was calculated and an indicator value index was elaborated (Dufrêne \& Legendre, 1997; see also Legendre \& Legendre, 1998). It comprised species' indicator values in FGS and CGS. The ecological preference of a weed for growth in one of the soil types rather than in the other type was determined by its higher scores (refer to Synoptic, Appendix 1). An arbitrarily threshold level of $25 \%$ chosen in the indicator value index, and the best indicator species for each soil type were selected from those species that have an indicator value (IndVal) $>25 \%$ and a statistically significant $P$-value $(a=0.05)$ of their calculated $X^{2}$ (Chi-square statistic, Pearson, 1900, see also Ryabko et al., 2004). Through the comparison of these values the effectiveness of the best indicator species was evaluated. For crop seasonality, the combined effects of the following items were considered as an express for the ecological preference of species: frequency and abundance values in winter crops (WC), summer crops (SC) and perennial crops (PC, OC); species seasonality measurement (SS) designated as all-the-year-round weeds (A), winter weeds (W), early-appearing winter weeds (Ws), summer weeds (S), early-appearing summer weeds (Sw) and species seasonal bias percentage (Sb\%); Mahgoub, 2019a, 2019b. For the ecological preference of species for crop diversification, the importance values for species ( $\mathrm{Fr}$ and $\mathrm{Ab}$ ) of pool all groups in addition to their $\mathrm{CV}$ (Coefficient of variation, Hendricks \& Robey, 1936, see also Krishnamoorthy \& Meesook, 2013); were taken as an express of the variable. The results were deposited in the synoptic table, Appendix 1 , and the maximum values between the subsets of the aforementioned items were denoted by bold red text. The methodology and mathematical formulation of the aforementioned items were given in Table 1. Species were ranked in the synoptic table in a descending order according to their frequency values. During analyses, four letters code for species was used by combining first two letters of genus name and species name and if similar with others, the subsequent ones were used (refer to synoptic table, Appendix 1). The Botanical Nomenclature of the recorded species have been updated from that appeared in Students' Flora of Egypt, Täckholm (1974) and in checklist of Boulos (2009) to a more recent Plant List, created by the Collaboration between the Royal Botanic Gardens (Kew), Missouri Botanical Garden (MO) and other collaborated institutions, Version 1.1, September 2013. Voucher specimens of each recorded species were collected and identified earlier in Cairo University Herbarium (CAI), where they deposited as Herbarium specimens and numbered by a serial collecting number (MAHGOUB'S collecting number).. 


\subsection{Diversity and Biostatistics}

The following software were used during Multivariate analyses (MVA):: VEGAN packages in R environment, ver. 3.6, 2019 (Oksanen et al., 2013); JUICE, ver. 7.1, 2020 (Tichý, 2001); PAST, ver. 4, 2020 (Hammer, 2001) and CANOCO, ver. 4.5 (ter Braak, 1988c). Agglomerative Hierarchical Clustering (AHC) was employed, as a clustering technique using Euclidean distance as a measure of dissimilarity and Ward's method (Minimum-variance clustering) as an agglomeration criterion (Orlóci, 1978), to classify the weed assemblages associated with the monitored crops into weed assemblages' groups (WAG) based on the variation in their floristic composition. The data were standardized prior to analyses. The identified WAG were named after the two most dominant species in each group (Whittaker, 1962). Their diversity was evaluated at different levels to estimate the extent of variation in vegetative structure. The following diversity indices were measured: Species richness (S) "Taxa_S" (Magurran et al., 2004, see also Chao, 2005); Shannon-Wiener diversity index (H) "Shannon_H" (Shannon \& Weaver, 1949, see also Pielou, 1975); Equitability (E) "Equitability_J" (Hill, 1973, see also Chao et al., 2005) and Dominance (D) “Dominance_D” (Simpson, 1949, see also Harper, 1999). The strength of linear correlation between them was determined by Person's correlation coefficient "r" (Pearson, 1895, see also Press et al., 1992). The phicoefficient of association $(\Phi)$ between species and the target vegetation units or WAG was used as a statistical measure of association or fidelity (Sokal \& Rohlf, 1995; Chytrý et al. 2002). Quantitative fidelity measure was applied using sum of all covers of the species in data set and target vegetation unit. The statistical significance of the phi coefficient was tested by calculating the chi-square statistic (Sokal \& Rohlf, 1995: 697, 736), at a level of significance of $0.05\left(X^{2}: a=0.05, P^{*}>3.84\right)$. The rule of thumb introduced by Lepš \& Šmilauer (2003) was applied and detrended correspondence analysis (DCA; Hill \& Gauch, 1980) had been used to estimate the compositional gradient in the vegetation data of the present study, to be < 4 SD (standard deviation units); thus, redundancy analysis (RDA; Van den Wollenberg, 1977 ) is the appropriate ordination method to perform direct gradient analysis (ter Braak \& Prentice, 1988). RDA, extracted and summarised the variation in species records (response variables) that can be explained by soil type, crop seasonality and crop diversification as explanatory variables. The soil physical properties and chemical properties which dominate the site were measured in FGS and CGS and were used as a comparison criterion during RDA. Whittaker's species turnover ( $\beta_{w}$; Whittaker, 1972, see also Tuomisto, 2010) was calculated depending on the presence-absence data to quantify the amount of species turnover among the two subunits of winter and summer half of the year, and the parameters were used as a comparison criterion during RDA, as well. A Monte Carlo permutation test (499 permutations; ter Braak, 1990) was used to test for significance of the eigenvalue of thefirst axis (RDA axis 1). The results of the analysis have been represented by an RDA correlation biplot for species vs environmental variables (Figure 3). Variation partitioning (VP; Borcard et al., 1992, Zelený, 2019) was employed with RDA and the variation was partialized out to determine the partial, linear effect of the three ecological preferences. The variation explained was compared by adjusted $\mathrm{R}^{2}$ values. The significance of fractions of interest was tested by applying ANOVA, permutation test for RDA under reduced model, 999 permutations. The results of VP analysis were displayed as a Venn diagram (Figure 4). 
The ecological preference of species for crop seasonality was evident through the results of AHC (Figure 2) which identified three weed communities or weed assemblages' groups (WAG). The weed assemblages associated with winter crops were clustered in WAG A or group Sonchus oleraceus -Rumex dentatus, summer crops in WAG B or group Bassia indica - Cyperus rotundus, perennial crops and orchards in WAG C or group Cynodon dactylon - Chenopodium murale. However, in addition to the dominant species in WAG, some other common species have characterized some sites or a number of relevés and formed alliances with less common types within the main identified group. According to the results of tabular comparison technique, the following associations were recognized at the level of alliance. In WAG A: Polypogon monspeliensis - Chenopodium album association and Melilotus indicusMalva parviflora associations in winter crops cultivated in CGS, Convolvulus arvensisBeta vulgaris and Vicia sativaBrassica nigra associations in those cultivated in FGS. In WAG B: Echinochloa colona Dinebra retroflexa and Aster squamatus -Amaranthus viridis associations in summer crops cultivated in FGS and Phyla nodiflora Portulaca oleracea and Panicum repensAmaranthus graecizans associations in those cultivated in CGS. In WAG C: Urtica urensSetaria viridis association in perennial crops and orchards cultivated in FGS and Erigeron bonariensis - Digitaria sanguinalis and Euphorbia peplusSisymbrium irio associations in those cultivated in CGS. The importance values of species presented in synoptic table (Appendix 1 ) indicated that most of them $(\approx 87 \%)$ were more affected by crop seasonality. They restrict their growth activity or showed their best performance either during the winter half of the year or during the summer half of the year. However, their likely association with the monitored agroecosystems differed. The fidelity measurements showed that a total of sixty species have fidelity to WAG A; 46 to WAG $B ; 44$ to WAG $C$. The less affected species by the variable of crop seasonality were the all-the-yearround weeds $(A=19 s p$.).. They had convergent records in winter crops and in summer crops, or all-theyear-round in perennial crops and orchards. Their fidelity measurement indicated that, 4 species had a greater degree of joint fidelity with WAG A, 11 species with WAG B and 4 species with WAG C. The most common of them was Cynodon dactylon and Cyperus rotundus, the two dominants of WAG B and WAG $\mathrm{C}$, respectively. Their $\mathrm{Sb} \%$ and $\mathrm{Ab}$ values indicated that the latter flourished more than the first in crops cultivated during the summer half of the year, while the first was more abundant during the above denoted season in perennial crops and orchards. The remaining 131-species were more affected by the variable. The first group of them included 40-species designated as Ws and Sw (23 sp. and $17 \mathrm{sp}$., respectively), of them 18-species had statistically significant fidelity measurements $\left(X^{2}: a=0.05, P^{*}>\right.$ 3.841). These species showed their best performance either in winter crops or in summer crops and had some tangible growth in the early cultivated crops during the corresponding other half of the year. This group included the other four dominant species of the identified WAG. The second group included 94species designated as W ( = $64 \mathrm{sp}$.) and $\mathrm{S}=(=27 \mathrm{sp}$.).. Some of them had statistically significant positive fidelity values $(\Phi)$ for their specified groups (WAG), while others showed statistically significant negative values for their association with non-specific groups. This group showed the highest ecological preference for crop seasonality and their records in their preferable season of growth were as twice or 
more than in the corresponding other half of the year. The degree of ecological preference of these species in response to the variable were recognized by comparing their values of seasonal bias (Sb\%).

The values of the diversity indices reflected the variability in the weed community structure of the identified WAG (A-C). The weed assemblages' group for winter crops (WAG A) scored the highest total species richness $(S=136 s p$.) with the lowest equitability value $(E=0.92)$, while the weed assemblages' group for summer crops (WAG B) scored the highest value of dominance ( $D=0.02)$ and the lowest species richness $(S=119 \mathrm{sp}$.).. The weed assemblages' group for orchards and perennial crops (WAG $\mathrm{C}$ ) scored the highest Equitability value and the highest Shannon-wiener diversity index value $(H=4.7, E=$ 0.96). Pearson's correlation coefficient value for the paired data of weed assemblages associated with WAG A (winter crops) and WAG B (summer crops), was not statistically significant $\left(r_{A B}=0.015 \& \mathrm{P}=\right.$ 0.853). However, it was statistically significant $(P<0.01)$ for the paired data of weed assemblages associated with each of both groups and those associated with perennial-crops and orchards; either at the level of WAG $\left(r_{A C}=0.450 ; r_{B C}=0.392\right)$; or at the level of the four categories of agronomic and horticultural crops presented in synoptic table $\left(r_{\mathrm{WP}}=0.608 ; r_{\mathrm{WO}}=0.428 ; r_{\mathrm{SP}}=0.594 ; r_{\mathrm{SO}}=0.363 ; r_{\mathrm{PO}}=\right.$ $0.661)$.

The results presented in synoptic table (Appendix 1) indicated also that the vast majority of the very common weeds ( $\mathrm{Fr}$ for "pool all groups" $=80-100 \%$ ) and the other less common weeds were affected by crop diversification. 136-species out of the recorded 150 most influential weeds had scored coefficient of variation $\left(C_{v}\right)$ which exceeded $50 \%$, but the more common species with the wider ecological amplitude were the less affected by the variable. The species $\mathrm{Fr}$ and $\mathrm{Ab}$ values had showed a medium strength of negative linear relationship with $C_{v}$. The more affected weeds (36-species) scored a very high coefficient of variation $\left(C_{v}\right)$ which exceeded $100 \%$. Although some of these species were recorded in all crop categories while others restrict their occurrence to one category or more, all of them showed a remarkable growth activity in one crop or more in certain soil type during their favorite growth season, while they were modestly represented or not recorded in others. Such weed performance was recorded in 13 out of the 30 agroecosystems monitored. Two species (Brni, Cipu) were recorded in Clover fields planted in FGS; $2 s p$. (Phpa, Orcr) in Broad bean fields planted in FGS; 1 sp. (Phpa) in Wheat fields planted in FGS; 4 sp. (Lesa, Siar, Sial, Malo)in Flax fields planted in FGS; one sp. (Sibe) in winter tomato plantations in CGS; $2 s p$. (Cool, Apth)in Cotton fields planted in FGS and one sp. (Sese) in those planted in CGS; one sp. (Amcr) in Maize fields planted in FGS; 6 sp. (Ecpr, Eccr, Cydf, Ecst, Amba, Amau) in Rice fields planted in FGS and 3 $s p$. (Cyal, Cydi, Ecpy) in those planted in CGS; one sp. (Brde)in Peanut fields planted in CGS; one $s p$. (Amma) in Watermelon cultivations in CGS; 4 sp. (Brre, Sovr, Fovu, Lepa) in Banana orchards planted in FCS and one sp. (Oxco) in those planted in CGS; one $s p$. (Sepu) in Mango orchards planted in FGS and one $s p$. (Oxco) in those planted in CGS; 4 sp. (Meno, Cama, Mecr, Rupi) in Date palm orchards planted in CGS (for species codes, refer to synoptic table, Appendix 1).

The indicator value of species (IndVal) indicated that 63-species showed ecological preference for growth in crops cultivated in fine grained soil (FGS) and 87-species in those crops cultivated in coarse grained 
soil (CGS). The six dominant species of the identified WAG (A-C) were the less affected by the variable. The other less common species were more affected with different degrees, of them 61-species had scored species' indicator value (IndVal) in their preferred soil type twice as high as in the other soil type (22-species IndVal: FGS $\geq 2$ CGS and 39-species IndVal: CGS $\geq 2$ FGS). The calculated chi-square statistic $\left(X^{2}\right)$ revealed that twenty-two species were statistically significant with $P$-value less than 0.05 , of them a total of 13 species ( $5 \mathrm{sp}$. in FGS and $8 \mathrm{sp}$. in CGS) were considered as best indicator species (indicator value $>25 \%$ ).

RDA results indicated that the constrained variance is much higher than the unconstrained one. The analysis explained $79.16 \%$ of the total variance. The permutation test indicated that both the model and eigenvalue "RAD axis 1" were statistically significant with $a=0.01$. The first axis explained $50.6 \%$ of the variation; with the second axis they explained a total of $69.3 \%$. The results of RDA displayed in the correlation biplot (Figure 3 ) indicated that "RDA axis 1" was positively correlated with soil content of sand (fine sand and coarse sand) while it was negatively correlated with soil content of clay, thus it can be interpreted as the "sand-clay" gradient. "RDA axis 2" was positively correlated with soil content of "CaCO3" while it was negatively correlated with soil content of " $\mathrm{Cl}$ ", thus it can be interpreted as the "calcium carbonate-chloride" gradient. The sets of object scores and explanatory variable scores indicated that the impact of crop diversification on the weed community structure associated with agronomic and horticultural crops cultivated in CGS is more than that in those cultivated in FGS. The angles between the vectors of the three ecological preferences reflected their (linear) correlation. Conceiving the objects ordination, we can realize that "the most influential species" have shown an ecological preference of variable growth in response to the three ecological preferences. The wider ecological amplitude species at the level of the major identified groups (WAG) were the less affected and most of them were ordinated around the centered axis. The vast majority of those at level of alliance within each WAG (associations) and the best indicator species were more affected and they were ordinated further far away. The codes of these species were denoted with a bold blue text in RDA correlation biplot (refer to synoptic table, Appendix 1, for corresponding botanical nomenclature). The right-angled projections of the object points of the six dominant species for WAG onto the vectors of the three environmental variables indicated their variability to attain maximum growth activity in response to ecological preferences. Four of them showed ecological preference for crops grown in FGS. However, the projection of the ordinated point of Rumex dentatus onto the variable vector of soil type, indicated that the variable's value of FGS realised for that object had higher value of the variable, relative to objects of the other dominants (Cyperus rotundus, Sonchus oleraceus and Chenopodium murale, respectively). Their coordinates also showed resistance and persistence of Rumex dentatus more than other species of growth in soils that contain a high concentration of "Cl" or in those which are irrigated with water that has a high concentration of chlorides. The other two species (Cynodon dactylon and Bassia indica) showed ecological preference for crops grown in CGS characterized by lower WHC, higher $\mathrm{PH}, \mathrm{HC}, \mathrm{CaCO}, \mathrm{HCO}$, $\mathrm{Na}, \mathrm{Ca}, \mathrm{Mg}, \mathrm{K} \& \mathrm{TSS}$, but the Bermuda grass excelled in soils characterized by more content of fine sand. Visualizing the RDA biplot we can realize that the above-mentioned species associations occurred as a result of more specific environmental conditions (ecological niche) within the major groups (WAG). Their 
species objects were ordinated closer together and had convergent response variable scores. Six-species were identified as the best indicator species in WAG A, seven-species were identified in WAG $B$ and ninespecies were identified in WAG C (refer to IndVal * $>25 \%$ in synoptic table, Appendix 1). Their effectiveness as best indicator species for certain ecological conditions could be recognized by their coordinates.

Partitioning the variation in response matrix (species records) between the three explanatory matrices (ecological preferences), had indicated that the partial linear effect for crop seasonality on the response data was greater than that of the other ecological preferences. The adjusted $\mathrm{R}^{2}$ values of the marginal and conditional effect of crop seasonality were $76.23 \% \& 25.71 \%$, respectively, while those of soil type and crop diversification were $46.75 \% \& 2.17 \% ; 47.69 \% \& 0.35 \%$, respectively (refer to Figure 4 ). The results indicated a strong correlation between the three explanatory variables and the shared variation explained by the them was much higher (Adj. $R^{2}=40.6 \%$ ) than the shared variation explained by only two of them (Adj.R2 $=0.4 \%-6.34 \%$ ). ANOVA results revealed that all simple (marginal) and conditional (partial) effects of the three predictors were significant at $P<0.001$.

- Discussion

The quest to bring new lands under cultivation is considered as the cornerstone for the agricultural policy in several countries. In Egypt, desert comprise about $95 \%$ of the total land surface and except for Nile Delta and the Fayium Oasis, only a narrow strip along the Nile is cultivated and the population is concentrated in these areas. It is not surprisingly that the land reclamation was not only the cornerstone of the Egyptian agricultural policy but it was also on the political agenda since the 1950s. It has been used as a remedy for a variety of problems e.g. desertification, alleviation of poverty, and reduction of graduate unemployment (Adriansen, 2009). The expansion in cultivation of non-traditional crops, especially in reclaimed land, has become one of the means of improving agricultural economic policy in the country. It usually concerns the shift of resources from low value agriculture to high value agriculture (Hayami and Otsuka, 1992). However, it is not only a move from occasional and low value crop(s) to high value crop(s), but also a need-based situation specific nonstop and vibrant idea. In the past few years, crop diversification played an essential role in the agricultural strategy and a diverse array of nontraditional crops has been cultivated. Hence, crop diversification was recognized as a new main driver of weed growth. However, crop cultivation is determined by several ecological factors and usually it is structured mainly by climatic conditions, edaphic qualities which characterize the soil itself (e.g. drainage, soil texture or chemical properties such as $\mathrm{pH}$, soil salinity, ...etc.) and crop seasonality which depends on crop genetic adaptation. Several phytosociological researches also indicated that the structure of vegetation groups is determined by the combined effects of a whole range of ecological factors (Mahgoub, 2019a and Gholinejad et al., 2012). Consequently, the topic of the present study included the measurement of preference for growth of the most influential weeds in three ecological preferences: crop diversification, soil type and crop seasonality. 
The values of diversity indices for the identified WAG (A-C) reflected the effectiveness of variability in the ecological preference of species for growth in response to the combined effect of the three ecological preferences. Their values varied from: $\mathrm{S}=119 s p .-136 s p ., \mathrm{H}=4.4-4.7, \mathrm{D}=0.01-0.02, \mathrm{E}=0.92-0.96$. WAG A was the more diverse group, the others showed lower heterogeneity in species composition and WAG B scored the highest " $D$ " while WAG $C$ scored the highest " $E$ ". Such increase in species diversity in WAG A (winter crops) is mainly attributed to more records of winter annuals in those crops cultivated in CGS in the northernmost part of Nile Delta and its adjoining east and west territories. Their appearance in ecological niche, matched to the presence of their specific environmental conditions which related first with the plentiful of water resources that are mainly available in arid habitats through high ratios of rainfall (Mahgoub, 2019b). The results deposited in the synoptic table and those of RDA with VP (Adj.R2 $=40.6 \%$ ), also indicated that the three ecological preferences were strongly correlated and the dominance of a species in one or more crops rather than it was in the others was a conclusion for its ecological preference for growth in response to the combined effect of these ecological preferences.

The species with the wider ecological amplitude were the less affected. Such difference in performance and wider ecological amplitude is often caused by phenotypic plasticity and heterogeneity (Shaltout \& Sharaf El-Din, 1988). However, the results of the analyses revealed that even the six dominant species in WAG (A-C), which had the widest ecological amplitude showed a noticeable variable preference to attain their maximum growth activity. Their indicator value (IndVal) indicated that four of them showed a preference for growth in the crops grown in FGS, while the other two showed a preference for growth in those cultivated in CGS. The impact of soil texture on above-ground net primary productivity (ANPP) of plant communities had been discussed by several researchers (Lane et al., 1998; Sala et al., 1988 and Le HouŽrou, 1984). They showed a variable performance as a response for crop seasonality and crop diversification, as well. Although, their frequency values indicated that they were recorded in all agroecosystems $(\mathrm{Fr}=100 \%)$, their abundance values in the different crop categories ranged from 46.9 to $73.3 \%$ and their coefficient of variation ranged from $C v=4.9$ to $61.4 \%$. Such vulnerability in their performance within their identified WAG (A-C) was the main reason for the record of eleven plant associations in these three macro-environmental classes through a tabular comparison technique. The species objects for these associations were ordinated closer together in RDA biplot. Their parameters revealed a more specific environmental conditions (ecological niche) through which the best indicators species were identified. Some species thrive well at the same soil conditions (Ellenberg et al., 1992), and the increase of convergent ecological conditions between sampling areas affects their floristic composition which depends on the species phenotypic plasticity (Mahgoub, 2019a).

The results of the current study also showed that the ecological preference of the most influential species (150 sp.) for growth in response to crop seasonality had the priority over the other ecological preferences. Most of them $(\approx 87 \%)$ were more affected by the variable and VP with RDA indicated that the variation explained by crop seasonality (marginal effect) was $76.23 \%$ of the cumulative variance $(79.16 \%)$. The ecological preference of species for crop seasonality was explicit through the results of the other analyses, as well. AHC separated the weed assemblages for winter crops into WAG A, summer crops in WAG B, perennial crops and orchards in WAG C, of whom 33 species had fidelity values (Ф) statistically 
significant for their identified groups. The results of Pearson's correlation coefficient indicated that the linear correlation between WAG A and WAG B was not statistically significant. In Egypt, 2 agronomic crops are usually grown in a seasonal sequence: a winter crop and a summer crop. However, the ecological preference of species for crop seasonality involves their ecological preference for crop diversification which depends on the type of crop cultivated as a conclusion of crop rotation techniques. Usually crop rotation is preferred rather than monocropping techniques in the vast majority of the surveyed sites. The results of VP with RDA indicated that the variation explained by the variable's conditional effect was $25.71 \%$ and the shared variation explained by crop seasonality and crop diversification was $46.94 \%$. The measurement of the coefficient of variation had indicated that 136 species scored $C_{v}>50 \%$, of them 34 species were more affected by crop diversification $\left(C_{v} \geq 100 \%\right)$. The angles between the vectors in RDA correlation biplot reflect such higher linear correlation between the two variables. The aforementioned results coincided with the previously cited conclusions of Mahgoub (2017, 2019a) and El Hadidi \& Kosinová (1971) which indicated that seasonality is an evident feature of weed plant growth, as it is equally evident in cropping rotation and a crop rotation is accompanied by a weedflora rotation. The impact of crop type was also discussed by Holzner (1978) and Fried et al. (2008) and they declared that the type of crop has the most significant impact on species composition. In his textbook, Modern Weed Control, Crafts (1975) cites several crops as potential weed smothering crops, and rotating crops with ones that kill weeds by choking them out can be a very effective method of weed control. It is a way to avoid the use of herbicides, and to gain the benefits of crop rotation (Lotz et al., 1991).

However, the cultivation of a certain crop type is a conclusion of what is available from natural resources as, soil type, quantity of farmland suitable for cultivation, plentiful of water, prevailing climatic conditions, ecological amplitude of the crop, human requirements, ...etc. (Mahgoub, 2019a). The results of the RDA confirmed the adoption of the type of crops grown through the diversification of crops to the type of soil, which affected the flowering composition of the groups of herbs associated with the cultivated crop. The higher strength of linear correlation observed in the RDA correlation biplot between crop diversification and CGS more than with FGS can be mainly attributed to that traditional crops were widely cultivated in the old farmlands (FGS) of the Nile Delta; while crop diversification through cultivation of non-traditional crops was preferred in reclaimed land (CGS) of the adjoining east and west territories. A total of 63species showed a preference for growth in the crops grown in FGS of them 22-species had IndVal: FGS $\geq$ 2 CGS and 87-species in those crops grown in CGS of them 39-species had IndVal: CGS $\geq 2$ FGS. Moreover, 22-species had statistically significant P-value of the calculated $X^{2}$ and 13-species of them were considered as best indicator species. VP with RDA had revealed that the shared variation explained by crop diversification and soil type was $41 \%$. Passioura (1991) had declared that soil structure-the spatial arrangement of individual particles, their aggregates, and of pores-plays a multifaceted key role in the factors determining crop and vegetation performance. Furthermore, Hamblin and Hamblin (1985) and Letey (1985) had indicated the effect of soil texture and properties on vegetation structure. It was also explicit that the preference for maximum growth activity of species is correlated with management practices and other soil physical and chemical properties. The coordinates of several species on RDA axis 
2 indicated their ecological preference for growth in calcareous soils. The addition of $\mathrm{CaCo} 3$ in the form of agricultural lime (ag lime) affects soil pH and soil nutrient availability. Calcareous soil PH is $>7.0$ and adding ag lime in suitable amounts has several advantages (supply Ca \& Mg, increase P availability, improve $\mathrm{N}$ fixation by legumes, enhanced $\mathrm{N}$ mineralization and nitrification, neutralize soil acidity caused by high concentration of $\mathrm{Cl}$, ...etc.). Gregorich et al. (1994), revealed that soil organic matter (SOM) is important in maintaining several soil properties and Voroney and Angers (1995), indicated that it can be controlled by management practices, including choice of cropping, management of crop residues and methods and intensity of tillage. In addition, Zhang et al., 2006; revealed that the pattern of assemblages within communities depend on both soil variables (e.g. N, P, K and organic matter) and other related environmental conditions as the topographic variables. It is explicit that the heterogeneous field conditions are inherent in most agricultural fields (Cook \& Bramley, 1998; Robert, 2002). Such heterogeneity can be manifested in several items as soil fertility (Reyniers et al., 2006), hydrological properties (Reyniers et al., 2006) and weed communities (Cardina et al., 1997; Rew \& Cousens, 2001). Despite that several researches revealed that weed community structure is affected by many factors, as farm management practices (Derksen et al., 1994; Andersson and Milberg, 1998; Thomas and Frick, 1993), crop type (Andersson and Milberg, 1998; Andreasen and Skovgaard, 2009), crop seasonality (ElDemerdash et al., 1997; Mahgoub, 2017), soil characteristics (Fried et al., 2008; Pinke et al., 2010, Mahgoub, 2019a, 2019b); however, much of the solution may be successful implementation of a crop diversification plan accompanied by robust weed control plans (weeding, hoeing, ploughing, Stale seed bed, farming practices, etc.).

- Conclusion

Weed control is a recalcitrant issue and the current study revealed that a portion of the solution is in a successful crop diversification plan, especially for crops grown for organic certification. The successful selection for a competitive crop that can be taken seriously as an adequate weed controlling mechanism in a crop rotation technique will cause the strongest population reduction of harmful weeds on infested farmland.

\section{References:}

\section{Abu Al-Izz MS (1977): Land Forms of Egypt. The American University of Cairo Press. Dar Al-Maarer, Cairo. Retrieved from https://aucpress.com/}

\section{Adriansen HK (2009). Land reclamation in Egypt: A study of life in the new lands. Geoforum 40: 664 - 674. https://doi.org/10.1016/j.geoforum.2009.05.006}


Ahmad Z, MulkKhan S, Abd_Allah FE, Alqarawi AA, Hashem A (2016). Weed species composition and distribution pattern in the maize crop under the influence of edaphic factors and farming practices: $A$ case study from Mardan, Pakistan. Saudi Journal of Biological Sciences 23: 741-748. https://doi.org/10.1016/j.sjbs.2016.07.001

\section{Amer A.M. \& Abd El-Ghani M. M. (1990). Studies on weed assemblages in croplands, Egypt. I. Broad bean fields. Egyptian Journal of Botany 33: 15-30. Retrieved from https://ejbo.journals.ekb.eg/}

Anderson MJ (2001). A new method for non-parametric multivariate analysis of variance. Austral Ecology 26:32-46. https://doi.org/10.1111/j.1442-9993.2001.01070.pp.x

Anderson MJ (2006). Distance-based tests for homogeneity of multivariate dispersions. Biometrics, 62, 245-253. https://doi.org/10.1111/j.1541-0420.2005.00440.x

\section{Andersson TN \& Milberg P (1998). Weed flora and the relative importance of site, crop, crop rotation, and nitrogen. Weed Sci., 46, pp. 30-38. https://doi.org/10.1017/S0043174500090135}

Andreasen C and Skovgaard IM (2009). Crop and soil factors of importance for the distribution of plant species on arable fields in Denmark. Agr. Ecosyst. Environ., 133 pp. 61-67.

https://doi.org/10.1016/j.agee.2009.05.003

Bastiaans L, Kropff MJ, Kempuchetty N, Rajan A \& Migo TR (1997). Can simulation models help design rice cultivars that are more competitive against weeds? Field Crops Research 51, 101-111.

https://doi.org/10.1016/s0378-4290(96)01046-5

Bastiaans L, Paolini R \& Bauman DT (2008). Focus on ecological weed management: what is hindering adoption? Weed Research 48, 481-491. https://doi.org/10.1111/j.1365-3180.2008.00662.x

Begum U and Ahmad U (2016). Biodiversity and ecological attributes of different weeds in wheat crop at Kohat, Pakistan. Pak. J. Weed Sci. 
Res., 24 (1):39-53. https://doi.org/10.28941/24-1(2018)-5

Biswas AK (1993). Land resources for sustainable agricultural development in Egypt. Ambio 22: 556-560. Retrieved from https://www.springer.com/journal/13280

Bonham CD (2013). Measurements for Terrestrial Vegetation. John Wiley \& Sons, Ltd. DOI:10.1002/9781118534540, https://doi.org/10.1002/9781118534540.ch4

Borcard DP, Legendre P, Drapeau P (1992). Partialling out the spatial component of ecological variation. Ecology. 73(3):1045-1055. https://doi.org/10.2307/1940179

Boulos L (2009). Flora of Egypt Checklist: Revised Annotated Edition. Cairo: Al Hadara Publishing. ISBN: 9789774760020 . Retrieved from https://www.summerfieldbooks.com/

Cain SA and Castro GM (1959). Manual of Vegetation analysis. Soil Science. 89 (6): pp. 359 https://doi.org/10.1097/00010694196006000-00011

Cardina J, Johnson GA \& Sparrow DH (1997). The nature and consequence of weed spatial distribution. Weed Science 45, 364373. https://doi.org/10.1017/s0043174500092997

Chao A, Chazdon RL, ColwelL RK \& Shen T (2005). A new statistical approach for assessing similarity of species composition with incidence and abundance data. Ecology Letters 8: 148-159 https://doi.org/10.1111/j.1461-0248.2004.00707.x

Chao A. (2005). Species richness estimation. Pages 7909-7916 in N. Balakrishnan, C. B. Read, and B. Vidakovic, eds. Encyclopedia of Statistical Sciences. New York, Wiley. Retrieved from https://www.wiley.com/en-us

Chytrý M, Tichý L, Holt J \& Botta-Dukát Z (2002). Determination of diagnostic species with statistical fidelity measures. Journal of Vegetation Science 13: 79-90. https://doi.org/10.1658/11009233(2002)013[0079:DODSWS]2.0.C0;2 
Clarke KR \& Warwick RM (2001a). Change in marine communities: an approach to statistical analysis and interpretation, 2nd edn. Plymouth Marin Laboratory, UK: PRIMER-E Ltd. Retrieved from https://pml.ac.uk/

Classification of Soils for Engineering Purposes (1985). Annual Book of ASTM Standards, D 2487-83, 04.08, American Society for Testing and Materials, pp. 395-408. https://doi.org/10.1520/d2487-98

Cook SE \& Bramley RGV (1998). Precision agriculture-opportunities, benefits and pitfalls of site-specific crop management in Australia. Australian Journal of Experimental Agriculture 38, 753-763.

https://doi.org/10.1071/ea97156

Crafts AS \& Robbins WW (1975). Modern weed control. Book; Berkeley: University of California Press pp.440 pp. Retrieved from https://www.worldcat.org/

Damgaard C (2009). On the distribution of plant abundance data. Ecological Informatics. 4 (2): 76-82.

https://doi.org/10.1016/j.ecoinf.2009.02.002

Derksen DA, Thomas AG, Lafond GP, Loeppky HA, Swanton CJ (1994). Impact of agronomic practices on weed communities: fallow within tillage systems. Weed Sci., 42, pp. 184-194. https://doi.org/10.1017/S0043174500080255

Dufrêne M \& Legendre P (1997). Species assemblages and indicator species: The need for a flexible asymmetrical approach. Ecological Monographs 67: 345-366. https://doi.org/10.2307/2963459

Egyptian Meteorological Authority (EMA). http://ema.gov.eg, Accessed September 2018.

Elbasiouny H and Elbehiry F (2019). Geology. Book Chapter published in World Soils Book Series (WSBS) on pages 93 to 109.

https://doi.org/10.1007/978-3-319-95516-2_6 
El-Demerdash MA, Hosni HA \& Al-Ashri N (1997). Distribution of the weed communities in the North-East Nile Delta, Egypt. Feddes Repertorium 108: 219-232. https://doi.org/10.1002/fedr.4921080311

\section{El-Gabaly MM, Gewaifel IM, Hassan MN \& Rozanov BG (1969). Soil} map and land resources of the United Arab Republic. Res. Bull. 22: 114. http://www.fao.org

El-Hadidi MN \& Kosinová J (1971). Studies on the weed flora of cultivated land in Egypt. 1. Preliminary survey. Mitteilungen Botanischen der Staatssammlung München 10: 354-367.

https://www.biodiversitylibrary.org/

Ellenberg H, Weber HE, Düll R, Wirth W, Werner W \& Paulien D (1992). Zeigerwerte von Pflanzen in Mitteleuropa. Scripta Geobotanica 18: 1258. https://doi.org/10.1002/fedr.19931040323

\section{Frick B and Thomas AG (1992). Weed surveys in different tillage systems in south western Ontario field crops. Can. J. Plant Sci. 72, 1337-1347. https://doi.org/10.4141/cjps92-166}

Fried G, Norton RL \& Reboud X (2008). Environmental and management factors determining weed species composition and diversity in France. Agriculture, Ecosystems and Environment 128: 68-76. Retrieved from https://www.journals.elsevier.com/agriculture-ecosystems-and-environment/

\section{Ghersa GM and Holt JS (1995). Using phenology prediction on weed management: a review. Weed Res. 35, 461-470. https://doi.org/10.1111/j.1365-3180.1995.tb01643.x}

Gholinejad B, Farajollahi A and Pouzesh H (2012). Environmental factors affecting on distribution of plant communities in semiarid area (Case study: Kamyaran rangelands, Iran). Annals of Biological Research 3 (8):3990-3993. ISSN 0976-123, Retrieved from www.scholarsresearchlibrary.com

Gregorich EG, Carter MR, Angers DA, Monreal CM, Ellert BH (1994). Towards a minimum data set to assess soil organic matter quality in agricultural soils. Can. J. Soil Sci. 74, 367-385.

https://doi.org/10.4141/cjss94-051

Hamblin AP, Hamblin J (1985). Root characteristics of some temperate legume species and varieties on deep, free-draining entisols. Australian Journal of Agricultural Research volume 36 issue 1 on page 63. 
Hammer, Ø., Harper, D. A. T., Ryan, P. D. 2001. PAST: Paleontological statistics software package for education and data analysis. Palaeontologia Electronica 4(1): 9pp. Retrieved from http://folk.uio.no/ohammer/past/

Harper DAT (1999). Numerical Palaeobiology. Computer-Based Modelling and Analysis of Fossils and their Distributions. $x+468$ pp. (ed.). Chichester, New York, Weinheim, Brisbane, Singapore, Toronto: John Wiley \& Sons. https://doi.org/10.1017/s0016756800334410

Hayami, Y and K Otsuka (1992): 'Beyond the Green Revolution: Agricultural Development Strategy into New Century' in Jock R Anderson (ed), Agricultural Technology: Policy Issues for the International Community, The World Bank, Washington, DC, US, pp 35. Retrieved from https://www.worldbank.org/

Hendricks WA, Robey KW (1936). "The Sampling Distribution of the Coefficient of Variation". The Annals of Mathematical Statistics. 7 (3): 129-32. https://doi.org/10.1214/aoms/1177732503

Hill MO \& Gauch HG (1980). Detrended correspondence analysis: an improved ordination technique. Vegetatio 42: 47-58. Retrieved from https://www.jstor.org/journal/vegetatio

Hill MO (1973). Diversity and evenness: a unifying notation and its consequences. Ecology. 54: 427-432. https://doi.org/10.2307/1934352

Holzner W (1978). Weed species and weed communities. Vegetatio38:13-20. https://doi.org/10.1007/bf00141295

Hoveizeh H (1997). Study of the vegetation cover and ecological characteristics in saline habitats of Hoor Shadegan. J. Res. Const. 34: 27-31. Retrieved from https://ascelibrary.org/journal/jcemd4

Joint Research Center, European Soil Data Centre (ESDAC) (2017). Geological map of Egypt. https://esdac.jrc.ec.europa.eu 
Kolar CS, Lodge DM (2001). Progress in invasion biology: predicting invaders. Trends in Ecology \& Evolution. 16 (4): 199-204. https://doi.org/10.1016/s0169-5347(01)02101-2

Krishnamoorthy K \& Meesook L (2013). "Improved tests for the equality of normal coefficients of variation". Computational Statistics. 29 (1-2): 215-232. doi:10.1007/s00180-013-0445-2

Lane DR, Coffin DP \& Lauenroth WK (1998). Effects of soil texture and precipitation on above-ground net primary productivity and vegetation structure across the Central Grassland region of the United States. Journal of Vegetation Science 9: 239-250. https://doi.org/10.2307/3237123

Le HouŽrou HN (1984). Rain use efficiency: a unifying concept in aridland ecology. J. Arid Environ. 7: 213-214. Retrieved from https://www.journals.elsevier.com/journal-of-arid-environments/

Legendre, P. \& Legendre, L. (1998) Numerical Ecology. Amsterdam, p. 853, the Netherlands: Elsevier. Published Aug 2000 in Ecological Modelling volume 132 issue 3 on pages 303 to 304 https://doi.org/10.1016/s0304-3800(00)00291-x

Lepš J \& Šmilauer P (2003). Multivariate Analysis of Ecological Data using CANOCO. International course on multivariate analysis, ISBN 0521891086, Cambridge University Press. regent.jcu.cz/maed

Letey J (1985). Irrigation uniformity as related to optimum crop production? additional research is needed. Irrigation Science volume 6 issue 4. https://doi.org/10.1007/bf00262470

Lotz LAP, Groeneveld RMW, Habekotte B, and Oene H (1991). Reduction of growth and reproduction of Cyperus esculentus by specific crops. Weed Research 31:153-160. https://doi.org/10.1111/j.13653180.1991.tb01754.x

Magurran AE \& McCarthy BC (2004). Measuring Biological Diversity. Blackwell Publishing, Oxford, 256 p. https://doi.org/10.2307/4126959

Mahgoub AMMA (2017). Diversity and Biostatistics of the plant life in the Northwest of the Delta, Egypt. Retrieved from 


\section{www.academia.edu., http://dx.doi.org/10.17632/4whz2tg553.1}

Mahgoub AMMA (2019a). The impact of five environmental factors on species distribution and weed community structure in the coastal farmland and adjacent territories in the northwest delta region, Egypt. Heliyon Volume 5, Issue 4, e01441. https://doi.org/10.1016/j.heliyon.2019.e01441

Mahgoub AMMA (2019b). Comparative view for the impact of five eco factors on species distribution and weed community structure in Isthmus of Suez and adjoining farmland east Nile delta, Egypt.

https://doi.org/10.1016/j.heliyon.2019.e02161

\section{Mashaly I, El-Said El Halawany; Gehan Omar (2002). Floristic features of Damietta area in the north east Nile Delta, Egypt. Taeckholmia,22(1):101-114. doi: 10.21608/taec.2002.12429}

Mashaly I, El-Shahaby O and El-Ameir Y (2010). Floristic Features of the canal bank habitats, Egypt. Journal of Environmental Sciences, Vol. 39, No. 4: 483-501. Retrieved from https://www.journals.elsevier.com/journal-of-environmental-sciences/

Menalled FND, Gross KL, Hammond M (2001). Weed aboveground and seedbank community responses to agricultural management systems. Ecological Society of America, 11 (6), pp. 1586-1601.

https://doi.org/10.1890/1051-0761(2001)011[1586:waascr]2.0.co;2

\section{Ministry of Agriculture and Land Reclamation (MALR), Department of soil survey, Egypt, http://www.agr-egypt.gov.eg, Accessed September 2018.}

\section{Müller-Dombois D \& Ellenberg H (1974). Aims and Methods of Vegetation Analysis. New York: John Wiley \& Sons. ISBN: 0-471- 62290-7. Retrieved from https://www.wiley.com/en-eg}

Nesser C, Dille JA, Krishnan G, Mortensen DA, Rawlinson JT, Martin AR, Bills LB (2004). Weed SOFT: a weed management decision support system. Weed Science 52, 115-122.

https://doi.org/10.1614/p2002-154

Oksanen J, Blanchet FG, Kindt R, Legendre P, Minchin PR, O'Hara RB, Simpson GL, Solymos P, Stevens MH, Wagner H (2016). Végan: Community Ecology Package. R-Package Version 3.6 http://CRAN.Rproject.org / Package/ Végan. Retrieved from https://cran.r-project.org/web/packages/vegan/index.html 
Orlóci L (1978). Multivariate analysis in vegetation research. W. Junk BV, The Hague. 451 p. https://doi.org/10.1007/978-94-017-5608-2

Passioura JB (1991). Soil structure and plant growth. Soil Research, volume 29 issue 6 on page 717. https://doi.org/10.1071/sr9910717

Pearson K (1895) "Notes on regression and inheritance in the case of two parents," Proceedings of the Royal Society of London, 58: 240242 https://doi.org/10.1098/rspl.1895.0041

Pearson K (1900). "On the criterion that a given system of deviations from the probable in the case of a correlated system of variables is such that it can be reasonably supposed to have arisen from random sampling" Philosophical Magazine. Series 5.50 (302): 157-175. doi:10.1080/14786440009463897

Pielou EC. (1975). Ecological Diversity. John Wiley and Sons., pp 165. https://doi.org/10.4319/lo.1977.22.1.0174b

Pinke G, Pál R and Botta-Dukát Z (2010). Effects of environmental factors on weed species composition of cereal and stubble fields in western Hungary. Cent. Eur. J. Biol., 5 (2), pp. 283-292.

https://doi.org/10.2478/s11535-009-0079-0

Press WH, Teukolsky SA, Vetterling WT \& Flannery BP (1992). Numerical Recipes in C. Cambridge University Press, Cambridge. https://doi.org/10.1017/s0263574700010675

Preston FW (1948). The Commonness, And Rarity, of Species. Ecology. 29 (3): on pages 254 to 283. https://doi.org/10.2307/1930989

Reichard SH \& Hamilton CW (1997). "Predicting invasions of woody plants introduced into North America". Conservation Biology. 11 (1): 193-203. doi:10.1046/j.1523-1739.1997. 95473.x

Rew LJ \& Cousens RD (2001). Spatial distribution of weeds in arable crops: are current sampling and analytical methods appropriate. Weed Research 41, 1-18. 
Reyniers M, Maertens K, Vrindts E \& De Baerdemaeker J (2006). Yield variability related to landscape properties of a loamy soil in central Belgium. Soil \& Tillage Research 88, 262-273.

https://doi.org/10.1016/j.still.2005.06.005

Robert PC (2002). Precision agriculture: a challenge for crop nutrition management. Plant and Soil 247, 143-149.

https://doi.org/10.1007/978-94-017-2789-1_11

Ryabko BYa, Stognienko VS, Shokin Yul (2004). "A new test for randomness and its application to some cryptographic problems". Journal of Statistical Planning and Inference. 123 (2): 365376.doi:10.1016/s0378-3758(03)00149-6

Ryan MR, Smith RG, Mortensen DA, Teasdale JR, Curran WS, Seidel R \& Shumway DL (2009). Weed-crop competition relationships differ between organic and conventional cropping systems. Weed Research Society Weed Research 49, 572-580 DOI: 10.1111/j.1365-3180.2009. 00736.X

Said R (1962). The Geology of Egypt. Elsevier, New York, Science 140, pp. 41. DOI: 10.1126/science.140.3562.41-a

\section{Sala OE., Parton WJ, Joyce LA \& Lauenroth WK (1988). Primary production of the central grassland region of the United States. Ecology 69: 40-45. https://doi.org/10.2307/1943158}

Salonen J (1993). Weed infestation and factors affecting weed incidence in spring cereals in Finland-a multivariate approach. Agricultural Science in Finland 2: 525-536. https://doi.org/10.23986/afsci.72678

Shaltout K. H. \& Sharaf El-Din A. (1988). Habitat types and plant communities along transect in the Nile Delta region. Feddes Repertorium 99: 153-162. https://doi.org/10.1002/fedr.4910990317

\section{Shaltout K. H., Sharaf El-Din A. \& El-Fahar R. A. (1992). Weed communities of the common crops in Nile Delta region. Flora 187: 329-339. https://doi.org/10.1016/s0367-2530(17)32240-5}

Shaltout KH, Hosni HA, El-Fahar RA and Ahmed DA (2015). Flora and vegetation of the different habitats of the western Mediterranean region of Egypt. Taeckholmia 35: 45-76.

https://doi.org/10.21608/taec.2015.12216 
Shannon CE and Weaver W (1949). The Mathematical Theory of Communication. Urbana: University of Illinois Press. https://doi.org/10.5962/bhl.title.104652

Simpson EH (1949). Measurement of diversity. Nature, 163:688. https://doi.org/10.1038/163688a0

Sokal RR \& Rohlf FJ (1995). Biometry: The Principles and Practices of Statistics in Biological Research. Book, 3rd ed. Freeman, New York, NY, US. pp. 880 / 899, ISBN 10: 0716724111. Retrieved from https://bok.cc/book/

Streibig JC (1979). Numerical methods illustrating the phytosociology of crops in relation to weed flora. Journal of Applied Ecology 16: 577-587. https://doi.org/10.2307/2402532

Täckholm V (1974). Students' Flora of Egypt, 2nd ed. Cairo: Cairo University Press. Ol: 14735955M. Retrieved from https://cu.edu.eg/

ter Braak CJF (1988c). CANOCO-a FORTRAN program for canonical community ordination by [partial] [detrended] [canonical] correspondence analysis, principal components analysis and redundancy analysis (version 2.1). Report LWA-88-02. Wageningen: Agricultural Mathematics Group. Retrieved from http://www.canoco5.com/

ter Braak CJF \& Prentice IC (1988). A theory of gradient analysis. Advances in Ecological Researches 18:271-317. https://doi.org/10.1016/S0065-2504(08)60183-X

ter Braak CJF (1990). Update Notes: CANOCO Version 3.1. Wageningen: Agricultural Mathematics Group. USA www.canoco.com.

The Plant List (2013). Version 1.1 Published on the Internet; www.theplantlist.org/ (accessed 1st January).

Thebaud C, Finzi AC, Affre L, Debussche M, Escarre J (1996). Assessing why two introduced Conyza differ in their ability to invade Mediterranean old fields. Ecology. 77 (3): 791-804.

https://doi.org/10.2307/2265502 


\section{Thomas AG, Frick BL (1993). Influence of tillage Systems on weed abundance in south western Ontario. Weed Technol., 7, pp. 699-705. https://doi.org/10.1017/S0890037X0003757X}

Tichý L (2001). JUICE 4.0. Program for management, analysis and classification of ecological data. Software user's guide. Department of Botany, Masaryk University, Brno, CZ. Retrieved from https://www.sci.muni.cz/botany/juice/

Torun H \& Uygur N (2018). Relationship between weed populations and crop rotation systems. Türkiye VII. Bitki Koruma Kongresi (Uluslararası Katılımlı), 14-17 Kasım 2018, Muğla, Türkiye. http://www.bitkikoruma2018.com

Tuomisto H (2010) A diversity of beta diversities: straightening up a concept gone awry. Part 1. Defining beta diversity as a function of alpha and gamma diversity. Ecography 33: 2-22. doi:10.1111/j.16000587.2009.05880

\section{Van den Wollenberg AL (1977). Redundancy analysis an alternative for canonical correlation analysis. Psychometrika volume 42 issue 2 on pages 207 to 219 . https://doi.org/10.1007/bf02294050}

Van Ittersum MK, Leffelaar PA, Van Keulen H, Kropff MJ, Bastiaans L \& Goudriaan J (2003). On approaches and applications of the Wageningen crop models. European Journal of Agronomy 18, 201234. https://doi.org/10.1016/s1161-0301(02)00106-5

\section{Verberk W (2011). "Explaining General Patterns in Species Abundance and Distributions". Nature Education Knowledge. 3 (10): 38 Retrieved from https://www.nature.com/scitable/knowledge/library/}

Voroney RP and Angers DA (1995). Analysis of the short-term effects of management on soil organic matter using the CENTURY model. In: Lal, R., et, al. (Eds.), Soil Management and Greenhouse Effect. Lewis Publishers, Boca Raton, FL, pp.113-120. https://doi.org/10.1201/9780203739310-10

\section{Whittaker RH (1962). Classification of natural communities. The Botanical Review volume 28 issue 1 on pages 1 to 239. https://doi.org/10.1007/bf02860872}

Whittaker RH (1972). Evolution and measurement of species diversity. TAXON volume 21 issue 2-3 on pages 213 to 251 


\section{https://doi.org/10.2307/1218190}

Zelený D. (2019). Analysis of community ecology data in R, Variation partitioning (constrained ordination). David Zelený website, retrieved from https://www.davidzeleny.net/anadat-

r/doku.php/en:varpart.

Zhang JT, Xi Y and Li. J (2006). The relationships between environment and plant communities in the middle part of Taihang Mountain Range, North China. Community Ecol. 7: 155-163.

https://doi.org/10.1556/comec.7.2006.2.3

\section{Zimdahl RL (2004). Weed-Crop Competition: A Review, 2nd Edn. Book, Blackwell Publishing, Ames, IA, USA. DOI:10.1002/9780470290224}

\section{Methodology}

\subsection{The study area}

Geography: The area of study is teardrop shaped (C. $\approx 27,231 \mathrm{Km}^{2}\left(10,514 \mathrm{mi}^{2}\right)$, Figure 1$)$. It comprised farmland of Nile Delta and adjoining east and west territories. The Nile Delta is one of the world's largest river deltas and is a rich agricultural region. The base of the Nile Delta represents the northern side of the study area, it covers some $240 \mathrm{~km}$ (150 mi) of Mediterranean coastline, from Alexandria in the west (coordinates: $31^{\circ} 12^{\prime} 27.3^{\prime \prime} \mathrm{N}, 29^{\circ} 55^{\prime} 09.0^{\prime \prime} E$; Latitude: 31.207592 , Longitude: 29.919168 ) to Port Said in the east $\left(31^{\circ} 16^{\prime} 09.6^{\prime \prime} \mathrm{N}, 32^{\circ} 18^{\prime} 04.1^{\prime \prime} \mathrm{E}\right.$; Lat, Long: $\left.31.269344,32.301133\right)$. From north to south the delta is approximately $160 \mathrm{~km}$ (99 mi) in length, from Baltim (31 $31^{\circ} 19.7^{\prime \prime} \mathrm{N}, 31^{\circ} 05^{\prime} 45.3 " \mathrm{E}$; Lat, Long: 31.555461 , $31.095909)$ to Cairo $\left(30^{\circ} 02^{\prime} 40.9^{\prime \prime} \mathrm{N}, 31^{\circ} 14^{\prime} 07.3^{\prime \prime E}\right.$; Lat, Long: 30.044698, 31.235365). The Suez Canal borders the study area from the east and the Western Desert from the west. The sample area comprises several types of ecological habitats: fertile lands of the Nile Delta; farmland facing the Nile including those of the Delta and its adjoining east and west territories; farmland at the fringes of salt marshes; those facing Mediterranean Sea; nearby the littoral sand dunes and reclaimed land in west-delta region and near to the western desert in west side, and at Isthmus of Suez and east-delta region in east side.

Climate: The Meteorological records of the area were obtained as a courtesy from the Egyptian Meteorological Authority "EMA", they include the records of the monthly averages of rainfall ( $\mathrm{mm})$, temperature $\left({ }^{\circ} \mathrm{C}\right)$, relative humidity and evaporation from 1931 to 2017 . The records revealed that from 100-200 mm (4-8 in) of rain falls on the delta area during an average year, and most of these falls in the winter months. The northernmost part is the wettest region of the sample area. With the onset of the winter season, at the end of October through the beginning of May, the northwestern delta area is exposed to 21 squalls. They are usually accompanied with lightning thunderstorms, low temperature, high wind speeds, and cloud bursts, which produce heavy rain showers. The Delta has relatively moderate temperatures, with highs usually not surpassing $31^{\circ} \mathrm{C}\left(88^{\circ} \mathrm{F}\right)$ in the summer. The area experiences its 
hottest temperatures in July and August, with a maximum average of $34^{\circ} \mathrm{C}\left(93^{\circ} \mathrm{F}\right)$. Winter temperatures are normally in the range of $9{ }^{\circ} \mathrm{C}\left(48^{\circ} \mathrm{F}\right)$ at nights to $19^{\circ} \mathrm{C}\left(66^{\circ} \mathrm{F}\right)$ in the daytime. Minimum temperature records usually don't seem to reach freezing. With cooler temperatures and some rain, the Nile Delta region becomes quite humid during the winter months, but the records of the southern meteorological stations for its adjoining east and west territories, away from the water bodies of the Mediterranean, were an express of drier atmosphere and higher rates of evaporation.

Soil type: According to the geological map of Egypt (ESDAC, 2017) and other geological researches (Elbasiouny \& Elbehiry, 2019 and Said, 1962), the following Quaternary formations were identified in the Nile Delta: recent Nile alluvium (Nile deposits); superficial deposits (sand dunes and sabkha deposits) and undivided quaternary (wadi and playa deposits, and raised beaches). The first formation included cultivated fertile land of Nile Delta and the other two included reclaimed land in the north, east and west territories of the study area. The surface of the Delta in the south is relatively smooth if compared to its surface in the north (Abu AL-Izz, 1977). Soils of the Nile Delta are mostly heavy in the texture and rather compact at the surface and the humus status of the soils is fairly well (EL-GABALY et al., 1969). Thus, all soils with exception of the northernmost part, are manmade and are regarded as anthropogenic variants of the Gleysols and Fluvisols (Shaltout et al., 1992). The chemical and mechanical analyses for the sites and localities of the study area were quoted from those recorded by the Ministry of Agriculture and Land Reclamation (MALR), Department of soil survey, Egypt, for respect of its authority and farmers property. The depth of soil horizon profiles were $0-30,30-60,60-90,90-120 \mathrm{~cm}$., in them the following soil properties were measured: 1) soil texture expressed as percentage for clay, silt, clay + silt, fine sand, coarse sand, 2) Water holding capacity (100 gm soil \%), 3) Hydrolytic conductivity (cm./hour), 4) Soil reaction $(\mathrm{PH}), 5)$ Main salts in water saturated soil extract: for cations $(\mathrm{Ca}, \mathrm{Mg}, \mathrm{Na}, \mathrm{K})$, and for anions $(\mathrm{CO} 3, \mathrm{HCO} 3, \mathrm{Cl}), 6)$ Total soluble salts (\%) and 7) Calcium carbonate content (CaCO3). The results of these analyses revealed that a soil type may dominate a sampling site (district), though another sampling site may comprise one or sometimes several soil types. Accordingly, the weight average was calculated to express the soil properties that dominate a certain area.

The surveyed sampling sites were clustered into two basic classes of soil type based on texture and a simple particle-size analysis according to USCS (The Unified Soil Classification System, ASTM International). The ecological preference for weed growth was rated according to soil texture from fine to coarse. Thus, the ecological preference of weed growth was measured in two basic soil types: Coarsegrained soils (CGS) which contain 50 percent or less of fines (including gravel soil and sandy soil), and Fine-grained soils (FGS) which contain more than 50 percent fines (silt and clay). Accordingly, out of the 64 sites surveyed a total of 40 sites were designated FGS and 24 sites CGS.

\subsection{Field sampling design and data collection}

Stratified sampling technique (Müller-Dombois \& Ellenberg, 1974: pp. 177-209) was used as an ecological sampling design method. A total of 64 georeferenced sampling sites were located randomly in 12 governorates, in the Nile Delta and its adjoining east and west territories to represent 30 agroecosystems 
which were defined at the level of cultivated crops (agronomic and horticultural crops) in the different ecological habitats (refer to Figure 1). In each sampling site, field plots (relevés) for the cultivated crops were surveyed, each of which $1000-1500 \mathrm{~m}^{2}$. Field plots were visited and the species were recorded in the different seasons through sequential seasonal excursions during 2018. Three visits during the winter half of the year from December to May (in January, March, and April) and the other three visits in the summer half of the year from June to November (in June, August, and September). The weed assemblages associated with the cultivated crops were recorded and the presence of species was taken to indicate degree of ecological success and sociological performance. Presence estimate percentage $\mathrm{PE} \%$ for species in each crop was calculated in the raw data set. One hundred and fifty species were categorized as "the most influential weed species" in the weed community structure associated with agricultural and horticultural crops out of the 555 species recorded. These weeds had PE\% $\geq 30 \%$ in at least in one of the agroecosystems monitored. The values of PE\% were calculated as an average from species records: in March \& April for the eight winter crops; in August \& September for the six summer crops; in August for the two melon crops and the highest average of their PE\% values for the two records groups of March-April and of August-September for perennial and orchard crops. For those weed species which are not included in these records but monitored in other months, their highest PE \% record was accepted in these months. The monitored crops were traditionally classified according to their season (period through which the crop occupies the field) and their position in the yearly agricultural rotation. Agronomic crops included: eight winter crops (WC): Clover, Wheat, Broad bean, Flax, Potato, Artichoke, Tomato "winter" and Vegetables "winter"; nine summer crops (SC): Cotton , Maize, Rice, Tomato "summer", Peanut, Soybean or Soya bean, Watermelon, Sweet-melon and Vegetables "summer" and two perennial crops (PC): Taro and Sugarcane. Horticultural crops (Orchards (OC)) included eleven genera: Citrus, Guava, Pear, Banana, Mango, Prunus, Apple, Olive, Pomegranate, Date palm and Grape. The first two letters were used as a crop code during analyses and if similar with others, the subsequent ones were used (for crop codes and botanical nomenclature, refer to Appendix 1). Some crops have two types of cultivations, e.g. Tomato plantings which are cultivated as a winter crop in sandy soils and as a summer crop in clay and clay loamy soils. It should be also pointed out that several genera monitored in orchards crops (e.g. Citrus and Prunus) included more than one cultivated species, subgenus, or varieties.

The ecological preference of species for soil type, crop seasonality and crop diversification were measured, based on their values of Fr (frequency, Cain, 1959; Bonham, 2013) and Ab (abundance, Preston, 1948; Damgaard, 2009; Verberk, 2011). Given these importance values, one can link the maximum species growth activity with its ecological preferences for a certain soil type in a certain crop type.

The comparison of species importance values ( $\mathrm{Fr}$ and $\mathrm{Ab}$ ) measured in crops cultivated in fine grain soils sites (FGS) with those measured in coarse grain soils sites (CGS), was taken as an express of the ecological preference of species for soil type. Indicator value of species (IndVal) was calculated and an indicator value index was elaborated (Dufrêne \& Legendre, 1997; see also Legendre \& Legendre, 1998). It comprised species' indicator values in FGS and CGS. The ecological preference of a weed for growth in 
one of the soil types rather than in the other type was determined by its higher scores (refer to Synoptic, Appendix 1). An arbitrarily threshold level of $25 \%$ chosen in the indicator value index, and the best indicator species for each soil type were selected from those species that have an indicator value (IndVal) $>25 \%$ and a statistically significant P-value $(a=0.05)$ of their calculated $X^{2}$ (Chi-square statistic, Pearson, 1900, see also Ryabko et al., 2004). Through the comparison of these values the effectiveness of the best indicator species was evaluated. For crop seasonality, the combined effects of the following items were considered as an express for the ecological preference of species: frequency and abundance values in winter crops (WC), summer crops (SC) and perennial crops (PC, OC); species seasonality measurement (SS) designated as all-the-year-round weeds (A), winter weeds (W), early-appearing winter weeds (Ws), summer weeds (S), early-appearing summer weeds (Sw) and species seasonal bias percentage (Sb\%); Mahgoub, 2019a, 2019b. For the ecological preference of species for crop diversification, the importance values for species ( $\mathrm{Fr}$ and $\mathrm{Ab}$ ) of pool all groups in addition to their $\mathrm{CV}$ (Coefficient of variation, Hendricks \& Robey, 1936, see also Krishnamoorthy \& Meesook, 2013); were taken as an express of the variable. The results were deposited in the synoptic table, Appendix 1 , and the maximum values between the subsets of the aforementioned items were denoted by bold red text. The methodology and mathematical formulation of the aforementioned items were given in Table 1. Species were ranked in the synoptic table in a descending order according to their frequency values. During analyses, four letters code for species was used by combining first two letters of genus name and species name and if similar with others, the subsequent ones were used (refer to synoptic table, Appendix 1). The Botanical Nomenclature of the recorded species have been updated from that appeared in Students' Flora of Egypt, Täckholm (1974) and in checklist of Boulos (2009) to a more recent Plant List, created by the Collaboration between the Royal Botanic Gardens (Kew), Missouri Botanical Garden (MO) and other collaborated institutions, Version 1.1, September 2013. Voucher specimens of each recorded species were collected and identified earlier in Cairo University Herbarium (CAl), where they deposited as Herbarium specimens and numbered by a serial collecting number (MAHGOUB'S collecting number).

\subsection{Diversity and Biostatistics}

The following software were used during Multivariate analyses (MVA): VEGAN packages in R environment, ver. 3.6, 2019 (Oksanen et al., 2013); JUICE, ver. 7.1, 2020 (Tichý, 2001); PAST, ver. 4, 2020 (Hammer, 2001) and CANOCO, ver. 4.5 (ter Braak, 1988c). Agglomerative Hierarchical Clustering (AHC) was employed, as a clustering technique using Euclidean distance as a measure of dissimilarity and Ward's method (Minimum-variance clustering) as an agglomeration criterion (Orlóci, 1978), to classify the weed assemblages associated with the monitored crops into weed assemblages' groups (WAG) based on the variation in their floristic composition. The data were standardized prior to analyses. The identified WAG were named after the two most dominant species in each group (Whittaker, 1962). Their diversity was evaluated at different levels to estimate the extent of variation in vegetative structure. The following diversity indices were measured: Species richness (S) "Taxa_S" (Magurran et al., 2004, see also Chao, 2005); Shannon-Wiener diversity index $(H)$ "Shannon_H" (Shannon \& Weaver, 1949, see also Pielou, 1975); Equitability (E) "Equitability_J” (Hill, 1973, see also Chao et al., 2005) and Dominance (D) 
“Dominance_D” (Simpson, 1949, see also Harper, 1999). The strength of linear correlation between them was determined by Person's correlation coefficient " $r$ " (Pearson, 1895, see also Press et al., 1992). The phicoefficient of association $(\Phi)$ between species and the target vegetation units or WAG was used as a statistical measure of association or fidelity (Sokal \& Rohlf, 1995; Chytrý et al. 2002). Quantitative fidelity measure was applied using sum of all covers of the species in data set and target vegetation unit. The statistical significance of the phi coefficient was tested by calculating the chi-square statistic (Sokal \& Rohlf, 1995: 697, 736), at a level of significance of $0.05\left(X^{2}: a=0.05, P^{*}>3.84\right)$. The rule of thumb introduced by Lepš \& Šmilauer (2003) was applied and detrended correspondence analysis (DCA; Hill \& Gauch, 1980) had been used to estimate the compositional gradient in the vegetation data of the present study, to be < 4 SD (standard deviation units); thus, redundancy analysis (RDA; Van den Wollenberg, 1977 ) is the appropriate ordination method to perform direct gradient analysis (ter Braak \& Prentice, 1988). RDA, extracted and summarised the variation in species records (response variables) that can be explained by soil type, crop seasonality and crop diversification as explanatory variables. The soil physical properties and chemical properties which dominate the site were measured in FGS and CGS and were used as a comparison criterion during RDA. Whittaker's species turnover ( $\beta_{w}$; Whittaker, 1972, see also Tuomisto, 2010) was calculated depending on the presence-absence data to quantify the amount of species turnover among the two subunits of winter and summer half of the year, and the parameters were used as a comparison criterion during RDA, as well. A Monte Carlo permutation test (499 permutations; ter Braak, 1990) was used to test for significance of the eigenvalue of the first axis (RDA axis 1). The results of the analysis have been represented by an RDA correlation biplot for species vs environmental variables (Figure 3). Variation partitioning (VP; Borcard et al., 1992, Zelený, 2019) was employed with RDA and the variation was partialized out to determine the partial, linear effect of the three ecological preferences. The variation explained was compared by adjusted $R^{2}$ values. The significance of fractions of interest was tested by applying ANOVA, permutation test for RDA under reduced model, 999 permutations. The results of VP analysis were displayed as a Venn diagram (Figure 4).

\section{Results}

The ecological preference of species for crop seasonality was evident through the results of AHC (Figure 2) which identified three weed communities or weed assemblages' groups (WAG). The weed assemblages associated with winter crops were clustered in WAG A or group Sonchus oleraceus - Rumex dentatus, summer crops in WAG B or group Bassia indica - Cyperus rotundus, perennial crops and orchards in WAG C or group Cynodon dactylon - Chenopodium murale. However, in addition to the dominant species in WAG, some other common species have characterized some sites or a number of relevés and formed alliances with less common types within the main identified group. According to the results of tabular comparison technique, the following associations were recognized at the level of alliance. In WAG A: Polypogon monspeliensis - Chenopodium album association and Melilotus indicus Malva parviflora associations in winter crops cultivated in CGS, Convolvulus arvensis - Beta vulgaris and Vicia sativa - Brassica nigra associations in those cultivated in FGS. In WAG B: Echinochloa colona Dinebra retroflexa and Aster squamatus-Amaranthus viridis associations in summer crops cultivated in 
FGS and Phyla nodiflora - Portulaca oleracea and Panicum repens - Amaranthus graecizans associations in those cultivated in CGS. In WAG C: Urtica urens - Setaria viridis association in perennial crops and orchards cultivated in FGS and Erigeron bonariensis - Digitaria sanguinalis and Euphorbia peplus - Sisymbrium irio associations in those cultivated in CGS. The importance values of species presented in synoptic table (Appendix 1 ) indicated that most of them $(\approx 87 \%)$ were more affected by crop seasonality. They restrict their growth activity or showed their best performance either during the winter half of the year or during the summer half of the year. However, their likely association with the monitored agroecosystems differed. The fidelity measurements showed that a total of sixty species have fidelity to WAG A; 46 to WAG B; 44 to WAG $C$. The less affected species by the variable of crop seasonality were the all-the-year-round weeds $(A=19 s p$.). They had convergent records in winter crops and in summer crops, or all-the-year-round in perennial crops and orchards. Their fidelity measurement indicated that, 4 species had a greater degree of joint fidelity with WAG A, 11 species with WAG $B$ and 4 species with WAG $C$. The most common of them was Cynodon dactylon and Cyperus rotundus, the two dominants of WAG B and WAG C, respectively. Their Sb\% and Ab values indicated that the latter flourished more than the first in crops cultivated during the summer half of the year, while the first was more abundant during the above denoted season in perennial crops and orchards. The remaining 131-species were more affected by the variable. The first group of them included 40-species designated as Ws and Sw (23 sp. and $17 \mathrm{sp}$., respectively), of them 18 -species had statistically significant fidelity measurements $\left(X^{2}: a=0.05, P^{*}\right.$ > 3.841). These species showed their best performance either in winter crops or in summer crops and had some tangible growth in the early cultivated crops during the corresponding other half of the year. This group included the other four dominant species of the identified WAG. The second group included 94species designated as $\mathrm{W}(=64 s p$.) and $\mathrm{S}=(=27 s p$.). Some of them had statistically significant positive fidelity values $(\Phi)$ for their specified groups (WAG), while others showed statistically significant negative values for their association with non-specific groups. This group showed the highest ecological preference for crop seasonality and their records in their preferable season of growth were as twice or more than in the corresponding other half of the year. The degree of ecological preference of these species in response to the variable were recognized by comparing their values of seasonal bias (Sb\%).

The values of the diversity indices reflected the variability in the weed community structure of the identified WAG (A-C). The weed assemblages' group for winter crops (WAG A) scored the highest total species richness $(S=136 s p$.) with the lowest equitability value $(E=0.92)$, while the weed assemblages' group for summer crops (WAG B) scored the highest value of dominance $(D=0.02)$ and the lowest species richness $(S=119 \mathrm{sp}$.). The weed assemblages' group for orchards and perennial crops (WAG C) scored the highest Equitability value and the highest Shannon-wiener diversity index value $(H=4.7, E=$ 0.96). Pearson's correlation coefficient value for the paired data of weed assemblages associated with WAG A (winter crops) and WAG B (summer crops), was not statistically significant $\left(r_{A B}=0.015 \& \mathrm{P}=\right.$ 0.853). However, it was statistically significant $(P<0.01)$ for the paired data of weed assemblages associated with each of both groups and those associated with perennial-crops and orchards; either at the level of WAG $\left(r_{A C}=0.450 ; r_{B C}=0.392\right)$; or at the level of the four categories of agronomic and 
horticultural crops presented in synoptic table $\left(r_{\mathrm{WP}}=0.608 ; r_{\mathrm{WO}}=0.428 ; r_{\mathrm{SP}}=0.594 ; r_{\mathrm{SO}}=0.363 ; r_{\mathrm{PO}}=\right.$ $0.661)$.

The results presented in synoptic table (Appendix 1) indicated also that the vast majority of the very common weeds ( $\mathrm{Fr}$ for "pool all groups" $=80-100 \%$ ) and the other less common weeds were affected by crop diversification. 136-species out of the recorded 150 most influential weeds had scored coefficient of variation $\left(C_{v}\right)$ which exceeded $50 \%$, but the more common species with the wider ecological amplitude were the less affected by the variable. The species $\mathrm{Fr}$ and $\mathrm{Ab}$ values had showed a medium strength of negative linear relationship with $C_{v}$. The more affected weeds (36-species) scored a very high coefficient of variation $\left(C_{v}\right)$ which exceeded $100 \%$. Although some of these species were recorded in all crop categories while others restrict their occurrence to one category or more, all of them showed a remarkable growth activity in one crop or more in certain soil type during their favorite growth season, while they were modestly represented or not recorded in others. Such weed performance was recorded in 13 out of the 30 agroecosystems monitored. Two species (Brni, Cipu) were recorded in Clover fields planted in FGS; $2 s p$. (Phpa, Orcr) in Broad bean fields planted in FGS; 1 sp. (Phpa) in Wheat fields planted in FGS; 4 sp. (Lesa, Siar, Sial, Malo) in Flax fields planted in FGS; one $s p$. (Sibe) in winter tomato plantations in CGS; $2 s p$. (Cool, Apth) in Cotton fields planted in FGS and one sp. (Sese) in those planted in CGS; one sp. (Amcr) in Maize fields planted in FGS; 6 sp. (Ecpr, Eccr, Cydf, Ecst, Amba, Amau) in Rice fields planted in FGS and 3 sp. (Cyal, Cydi, Ecpy) in those planted in CGS; one sp. (Brde) in Peanut fields planted in CGS; one $s p$. (Amma) in Watermelon cultivations in CGS; 4 sp. (Brre, Sovr, Fovu, Lepa) in Banana orchards planted in FCS and one sp. (Oxco) in those planted in CGS; one $s p$. (Sepu) in Mango orchards planted in FGS and one $s p$. (Oxco) in those planted in CGS; 4 sp. (Meno, Cama, Mecr, Rupi) in Date palm orchards planted in CGS (for species codes, refer to synoptic table, Appendix 1).

The indicator value of species (IndVal) indicated that 63-species showed ecological preference for growth in crops cultivated in fine grained soil (FGS) and 87-species in those crops cultivated in coarse grained soil (CGS). The six dominant species of the identified WAG (A-C) were the less affected by the variable. The other less common species were more affected with different degrees, of them 61-species had scored species' indicator value (IndVal) in their preferred soil type twice as high as in the other soil type (22-species IndVal: FGS $\geq 2$ CGS and 39-species IndVal: CGS $\geq 2$ FGS). The calculated chi-square statistic $\left(X^{2}\right)$ revealed that twenty-two species were statistically significant with P-value less than 0.05 , of them a total of 13 species ( $5 \mathrm{sp}$. in FGS and $8 \mathrm{sp}$. in CGS) were considered as best indicator species (indicator value $>25 \%$ ).

RDA results indicated that the constrained variance is much higher than the unconstrained one. The analysis explained $79.16 \%$ of the total variance. The permutation test indicated that both the model and eigenvalue "RAD axis 1 " were statistically significant with $a=0.01$. The first axis explained $50.6 \%$ of the variation; with the second axis they explained a total of $69.3 \%$. The results of RDA displayed in the correlation biplot (Figure 3 ) indicated that "RDA axis 1 " was positively correlated with soil content of sand (fine sand and coarse sand) while it was negatively correlated with soil content of clay, thus it can be 
interpreted as the "sand - clay" gradient. "RDA axis 2" was positively correlated with soil content of "CaCO3" while it was negatively correlated with soil content of " $\mathrm{Cl}$ ", thus it can be interpreted as the "calcium carbonate - chloride" gradient. The sets of object scores and explanatory variable scores indicated that the impact of crop diversification on the weed community structure associated with agronomic and horticultural crops cultivated in CGS is more than that in those cultivated in FGS. The angles between the vectors of the three ecological preferences reflected their (linear) correlation. Conceiving the objects ordination, we can realize that "the most influential species" have shown an ecological preference of variable growth in response to the three ecological preferences. The wider ecological amplitude species at the level of the major identified groups (WAG) were the less affected and most of them were ordinated around the centered axis. The vast majority of those at level of alliance within each WAG (associations) and the best indicator species were more affected and they were ordinated further far away. The codes of these species were denoted with a bold blue text in RDA correlation biplot (refer to synoptic table, Appendix 1, for corresponding botanical nomenclature). The right-angled projections of the object points of the six dominant species for WAG onto the vectors of the three environmental variables indicated their variability to attain maximum growth activity in response to ecological preferences. Four of them showed ecological preference for crops grown in FGS. However, the projection of the ordinated point of Rumex dentatus onto the variable vector of soil type, indicated that the variable's value of FGS realised for that object had higher value of the variable, relative to objects of the other dominants (Cyperus rotundus, Sonchus oleraceus and Chenopodium murale, respectively). Their coordinates also showed resistance and persistence of Rumex dentatus more than other species of growth in soils that contain a high concentration of "Cl" or in those which are irrigated with water that has a high concentration of chlorides. The other two species (Cynodon dactylon and Bassia indica) showed ecological preference for crops grown in CGS characterized by lower $\mathrm{WHC}$, higher $\mathrm{PH}, \mathrm{HC}, \mathrm{CaCO}$, $\mathrm{HCO}$, $\mathrm{Na}, \mathrm{Ca}, \mathrm{Mg}, \mathrm{K} \& \mathrm{TSS}$, but the Bermuda grass excelled in soils characterized by more content of fine sand. Visualizing the RDA biplot we can realize that the above-mentioned species associations occurred as a result of more specific environmental conditions (ecological niche) within the major groups (WAG). Their species objects were ordinated closer together and had convergent response variable scores. Six-species were identified as the best indicator species in WAG A, seven-species were identified in WAG $B$ and ninespecies were identified in WAG C (refer to IndVal * $>25 \%$ in synoptic table, Appendix 1 ). Their effectiveness as best indicator species for certain ecological conditions could be recognized by their coordinates.

Partitioning the variation in response matrix (species records) between the three explanatory matrices (ecological preferences), had indicated that the partial linear effect for crop seasonality on the response data was greater than that of the other ecological preferences. The adjusted $\mathrm{R}^{2}$ values of the marginal and conditional effect of crop seasonality were $76.23 \% \& 25.71 \%$, respectively, while those of soil type and crop diversification were $46.75 \% \& 2.17 \% ; 47.69 \% \& 0.35 \%$, respectively (refer to Figure 4 ). The results indicated a strong correlation between the three explanatory variables and the shared variation explained by the them was much higher (Adj. $R^{2}=40.6 \%$ ) than the shared variation explained by only two of them 
(Adj.R2 $=0.4 \%-6.34 \%$ ). ANOVA results revealed that all simple (marginal) and conditional (partial) effects of the three predictors were significant at $\mathrm{P}<0.001$.

\section{Discussion}

The quest to bring new lands under cultivation is considered as the cornerstone for the agricultural policy in several countries. In Egypt, desert comprise about $95 \%$ of the total land surface and except for Nile Delta and the Fayium Oasis, only a narrow strip along the Nile is cultivated and the population is concentrated in these areas. It is not surprisingly that the land reclamation was not only the cornerstone of the Egyptian agricultural policy but it was also on the political agenda since the 1950s. It has been used as a remedy for a variety of problems e.g. desertification, alleviation of poverty, and reduction of graduate unemployment (Adriansen, 2009). The expansion in cultivation of non-traditional crops, especially in reclaimed land, has become one of the means of improving agricultural economic policy in the country. It usually concerns the shift of resources from low value agriculture to high value agriculture (Hayami and Otsuka, 1992). However, it is not only a move from occasional and low value crop(s) to high value crop(s), but also a need-based situation specific nonstop and vibrant idea. In the past few years, crop diversification played an essential role in the agricultural strategy and a diverse array of nontraditional crops has been cultivated. Hence, crop diversification was recognized as a new main driver of weed growth. However, crop cultivation is determined by several ecological factors and usually it is structured mainly by climatic conditions, edaphic qualities which characterize the soil itself (e.g. drainage, soil texture or chemical properties such as $\mathrm{pH}$, soil salinity, ...etc.) and crop seasonality which depends on crop genetic adaptation. Several phytosociological researches also indicated that the structure of vegetation groups is determined by the combined effects of a whole range of ecological factors (Mahgoub, 2019a and Gholinejad et al., 2012). Consequently, the topic of the present study included the measurement of preference for growth of the most influential weeds in three ecological preferences: crop diversification, soil type and crop seasonality.

The values of diversity indices for the identified WAG (A-C) reflected the effectiveness of variability in the ecological preference of species for growth in response to the combined effect of the three ecological preferences. Their values varied from: $\mathrm{S}=119 s p .-136 s p ., \mathrm{H}=4.4-4.7, \mathrm{D}=0.01-0.02, \mathrm{E}=0.92-$ 0.96. WAG A was the more diverse group, the others showed lower heterogeneity in species composition and WAG B scored the highest " $D$ " while WAG $C$ scored the highest " $E$ ". Such increase in species diversity in WAG A (winter crops) is mainly attributed to more records of winter annuals in those crops cultivated in CGS in the northernmost part of Nile Delta and its adjoining east and west territories. Their appearance in ecological niche, matched to the presence of their specific environmental conditions which related first with the plentiful of water resources that are mainly available in arid habitats through high ratios of rainfall (Mahgoub, 2019b). The results deposited in the synoptic table and those of RDA with VP (Adj.R2 $=40.6 \%$, also indicated that the three ecological preferences were strongly correlated and the dominance of a species in one or more crops rather than it was in the others was a conclusion for its ecological preference for growth in response to the combined effect of these ecological preferences. 
The species with the wider ecological amplitude were the less affected. Such difference in performance and wider ecological amplitude is often caused by phenotypic plasticity and heterogeneity (Shaltout \& Sharaf El-Din, 1988). However, the results of the analyses revealed that even the six dominant species in WAG (A-C), which had the widest ecological amplitude showed a noticeable variable preference to attain their maximum growth activity. Their indicator value (IndVal) indicated that four of them showed a preference for growth in the crops grown in FGS, while the other two showed a preference for growth in those cultivated in CGS. The impact of soil texture on above-ground net primary productivity (ANPP) of plant communities had been discussed by several researchers (Lane et al., 1998; Sala et al., 1988 and Le HouŽrou, 1984). They showed a variable performance as a response for crop seasonality and crop diversification, as well. Although, their frequency values indicated that they were recorded in all agroecosystems $(\mathrm{Fr}=100 \%)$, their abundance values in the different crop categories ranged from 46.9 to $73.3 \%$ and their coefficient of variation ranged from $C v=4.9$ to $61.4 \%$. Such vulnerability in their performance within their identified WAG (A-C) was the main reason for the record of eleven plant associations in these three macro-environmental classes through a tabular comparison technique. The species objects for these associations were ordinated closer together in RDA biplot. Their parameters revealed a more specific environmental conditions (ecological niche) through which the best indicators species were identified. Some species thrive well at the same soil conditions (Ellenberg et al., 1992), and the increase of convergent ecological conditions between sampling areas affects their floristic composition which depends on the species phenotypic plasticity (Mahgoub, 2019a).

The results of the current study also showed that the ecological preference of the most influential species (150 sp.) for growth in response to crop seasonality had the priority over the other ecological preferences. Most of them $(\approx 87 \%)$ were more affected by the variable and VP with RDA indicated that the variation explained by crop seasonality (marginal effect) was $76.23 \%$ of the cumulative variance $(79.16 \%)$. The ecological preference of species for crop seasonality was explicit through the results of the other analyses, as well. AHC separated the weed assemblages for winter crops into WAG A, summer crops in WAG B, perennial crops and orchards in WAG C, of whom 33 species had fidelity values $(\Phi)$ statistically significant for their identified groups. The results of Pearson's correlation coefficient indicated that the linear correlation between WAG A and WAG B was not statistically significant. In Egypt, 2 agronomic crops are usually grown in a seasonal sequence: a winter crop and a summer crop. However, the ecological preference of species for crop seasonality involves their ecological preference for crop diversification which depends on the type of crop cultivated as a conclusion of crop rotation techniques. Usually crop rotation is preferred rather than monocropping techniques in the vast majority of the surveyed sites. The results of VP with RDA indicated that the variation explained by the variable's conditional effect was $25.71 \%$ and the shared variation explained by crop seasonality and crop diversification was $46.94 \%$. The measurement of the coefficient of variation had indicated that 136 species scored $C_{V}>50 \%$, of them 34 species were more affected by crop diversification $\left(C_{V} \geq 100 \%\right)$. The angles between the vectors in RDA correlation biplot reflect such higher linear correlation between the two variables. The aforementioned results coincided with the previously cited conclusions of Mahgoub (2017, 2019a) and El Hadidi \& Kosinová (1971) which indicated that seasonality is an evident feature of weed 
plant growth, as it is equally evident in cropping rotation and a crop rotation is accompanied by a weedflora rotation. The impact of crop type was also discussed by Holzner (1978) and Fried et al. (2008) and they declared that the type of crop has the most significant impact on species composition. In his textbook, Modern Weed Control, Crafts (1975) cites several crops as potential weed smothering crops, and rotating crops with ones that kill weeds by choking them out can be a very effective method of weed control. It is a way to avoid the use of herbicides, and to gain the benefits of crop rotation (Lotz et al., 1991).

However, the cultivation of a certain crop type is a conclusion of what is available from natural resources as, soil type, quantity of farmland suitable for cultivation, plentiful of water, prevailing climatic conditions, ecological amplitude of the crop, human requirements, ...etc. (Mahgoub, 2019a). The results of the RDA confirmed the adoption of the type of crops grown through the diversification of crops to the type of soil, which affected the flowering composition of the groups of herbs associated with the cultivated crop. The higher strength of linear correlation observed in the RDA correlation biplot between crop diversification and CGS more than with FGS can be mainly attributed to that traditional crops were widely cultivated in the old farmlands (FGS) of the Nile Delta; while crop diversification through cultivation of non-traditional crops was preferred in reclaimed land (CGS) of the adjoining east and west territories. A total of 63species showed a preference for growth in the crops grown in FGS of them 22-species had IndVal: FGS $\geq$ 2 CGS and 87-species in those crops grown in CGS of them 39-species had IndVal: CGS $\geq 2$ FGS. Moreover, 22-species had statistically significant P-value of the calculated $X^{2}$ and 13-species of them were considered as best indicator species. VP with RDA had revealed that the shared variation explained by crop diversification and soil type was $41 \%$. Passioura (1991) had declared that soil structure-the spatial arrangement of individual particles, their aggregates, and of pores-plays a multifaceted key role in the factors determining crop and vegetation performance. Furthermore, Hamblin and Hamblin (1985) and Letey (1985) had indicated the effect of soil texture and properties on vegetation structure. It was also explicit that the preference for maximum growth activity of species is correlated with management practices and other soil physical and chemical properties. The coordinates of several species on RDA axis 2 indicated their ecological preference for growth in calcareous soils. The addition of $\mathrm{CaCo} 3$ in the form of agricultural lime (ag lime) affects soil pH and soil nutrient availability. Calcareous soil PH is $>7.0$ and adding ag lime in suitable amounts has several advantages (supply Ca \& Mg, increase P availability, improve $\mathrm{N}$ fixation by legumes, enhanced $\mathrm{N}$ mineralization and nitrification, neutralize soil acidity caused by high concentration of $\mathrm{Cl}$,...etc.). Gregorich et al. (1994), revealed that soil organic matter (SOM) is important in maintaining several soil properties and Voroney and Angers (1995), indicated that it can be controlled by management practices, including choice of cropping, management of crop residues and methods and intensity of tillage. In addition, Zhang et al., 2006; revealed that the pattern of assemblages within communities depend on both soil variables (e.g. N, P, K and organic matter) and other related environmental conditions as the topographic variables. It is explicit that the heterogeneous field conditions are inherent in most agricultural fields (Cook \& Bramley, 1998; Robert, 2002). Such heterogeneity can be manifested in several items as soil fertility (Reyniers et al., 2006), hydrological properties (Reyniers et al., 2006) and weed communities (Cardina et al., 1997; Rew \& Cousens, 2001). 
Despite that several researches revealed that weed community structure is affected by many factors, as farm management practices (Derksen et al., 1994; Andersson and Milberg, 1998; Thomas and Frick, 1993), crop type (Andersson and Milberg, 1998; Andreasen and Skovgaard, 2009), crop seasonality (ElDemerdash et al., 1997; Mahgoub, 2017), soil characteristics (Fried et al., 2008; Pinke et al., 2010, Mahgoub, 2019a, 2019b); however, much of the solution may be successful implementation of a crop diversification plan accompanied by robust weed control plans (weeding, hoeing, ploughing, Stale seed bed, farming practices, etc.).

\section{Conclusions}

Weed control is a recalcitrant issue and the current study revealed that a portion of the solution is in a successful crop diversification plan, especially for crops grown for organic certification. The successful selection for a competitive crop that can be taken seriously as an adequate weed controlling mechanism in a crop rotation technique will cause the strongest population reduction of harmful weeds on infested farmland.

\section{References}

Abu Al-Izz MS (1977): Land Forms of Egypt. The American University of Cairo Press. Dar Al-Maarer, Cairo. Retrieved from https://aucpress.com/

Adriansen HK (2009). Land reclamation in Egypt: A study of life in the new lands. Geoforum 40: 664 674. https://doi.org/10.1016/j.geoforum.2009.05.006

Ahmad Z, MulkKhan S, Abd_Allah FE, Alqarawi AA, Hashem A (2016). Weed species composition and distribution pattern in the maize crop under the influence of edaphic factors and farming practices: $A$ case study from Mardan, Pakistan. Saudi Journal of Biological Sciences 23: 741-748.

https://doi.org/10.1016/j.sjbs.2016.07.001

Amer A.M. \& Abd El-Ghani M.M. (1990). Studies on weed assemblages in croplands, Egypt. I. Broad bean fields. Egyptian Journal of Botany 33: 15-30. Retrieved from https:// ejbo.journals.ekb.eg/

Anderson MJ (2001). A new method for non-parametric multivariate analysis of variance. Austral Ecology 26:32-46. https://doi.org/10.1111/j.1442-9993.2001.01070.pp.x

Anderson MJ (2006). Distance-based tests for homogeneity of multivariate dispersions. Biometrics, 62 , 245-253. https://doi.org/10.1111/j.1541-0420.2005.00440.x

Andersson TN \& Milberg P (1998). Weed flora and the relative importance of site, crop, crop rotation, and nitrogen. Weed Sci., 46, pp. 30-38. https://doi.org/10.1017/S0043174500090135

Andreasen C and Skovgaard IM (2009). Crop and soil factors of importance for the distribution of plant species on arable fields in Denmark. Agr. Ecosyst. Environ., 133 pp. 61-67. 
https://doi.org/10.1016/j.agee.2009.05.003

Bastiaans L, Kropff MJ, Kempuchetty N, Rajan A \& Migo TR (1997). Can simulation models help design rice cultivars that are more competitive against weeds? Field Crops Research 51, 101-111. https://doi.org/10.1016/s0378-4290(96)01046-5

Bastiaans L, Paolini R \& Bauman DT (2008). Focus on ecological weed management: what is hindering adoption? Weed Research 48, 481-491. https://doi.org/10.1111/j.1365-3180.2008.00662.x

Begum U and Ahmad U (2016). Biodiversity and ecological attributes of different weeds in wheat crop at Kohat, Pakistan. Pak. J. Weed Sci. Res., 24 (1):39-53. https://doi.org/10.28941/24-1(2018)-5

Biswas AK (1993). Land resources for sustainable agricultural development in Egypt. Ambio 22: 556560. Retrieved from https://www.springer.com/journal/13280

Bonham CD (2013). Measurements for Terrestrial Vegetation. John Wiley \& Sons, Ltd.

DOI:10.1002/9781118534540, https://doi.org/10.1002/9781118534540.ch4

Borcard DP, Legendre P, Drapeau P (1992). Partialling out the spatial component of ecological variation. Ecology. 73(3):1045-1055. https://doi.org/10.2307/1940179

Boulos L (2009). Flora of Egypt Checklist: Revised Annotated Edition. Cairo: Al Hadara Publishing. ISBN: 9789774760020. Retrieved from https://www.summerfieldbooks.com/

Cain SA and Castro GM (1959). Manual of Vegetation analysis. Soil Science. 89 (6): pp. 359 https://doi.org/10.1097/00010694-196006000-00011

Cardina J, Johnson GA \& Sparrow DH (1997). The nature and consequence of weed spatial distribution. Weed Science 45, 364-373. https://doi.org/10.1017/s0043174500092997

Chao A, Chazdon RL, ColwelL RK \& Shen T (2005). A new statistical approach for assessing similarity of species composition with incidence and abundance data. Ecology Letters 8: 148-159 https://doi.org/10.1111/j.1461-0248.2004.00707.x

Chao A. (2005). Species richness estimation. Pages 7909-7916 in N. Balakrishnan, C. B. Read, and B. Vidakovic, eds. Encyclopedia of Statistical Sciences. New York, Wiley. Retrieved from https://www.wiley.com/en-us

Chytrý M, Tichý L, Holt J \& Botta-Dukát Z (2002). Determination of diagnostic species with statistical fidelity measures. Journal of Vegetation Science 13: 79-90. https://doi.org/10.1658/11009233(2002)013[0079:DODSWS]2.0.C0;2

Clarke KR \& Warwick RM (2001a). Change in marine communities: an approach to statistical analysis and interpretation, 2nd edn. Plymouth Marin Laboratory, UK: PRIMER-E Ltd. Retrieved from 
https://pml.ac.uk/

Classification of Soils for Engineering Purposes (1985). Annual Book of ASTM Standards, D 2487-83, 04.08, American Society for Testing and Materials, pp. 395-408. https://doi.org/10.1520/d2487-98

Cook SE \& Bramley RGV (1998). Precision agriculture - opportunities, benefits and pitfalls of site-specific crop management in Australia. Australian Journal of Experimental Agriculture 38, 753-763.

https://doi.org/10.1071/ea97156

Crafts AS \& Robbins WW (1975). Modern weed control. Book; Berkeley: University of California Press pp.440 pp. Retrieved from https://www.worldcat.org/

Damgaard C (2009). On the distribution of plant abundance data. Ecological Informatics. 4 (2): 76-82. https://doi.org/10.1016/j.ecoinf.2009.02.002

Derksen DA, Thomas AG, Lafond GP, Loeppky HA, Swanton CJ (1994). Impact of agronomic practices on weed communities: fallow within tillage systems. Weed Sci., 42, pp. 184-194.

https://doi.org/10.1017/S0043174500080255

Dufrêne M \& Legendre P (1997). Species assemblages and indicator species: The need for a flexible asymmetrical approach. Ecological Monographs 67: 345-366. https://doi.org/10.2307/2963459

Egyptian Meteorological Authority (EMA). http://ema.gov.eg, Accessed September 2018.

Elbasiouny H and Elbehiry F (2019). Geology. Book Chapter published in World Soils Book Series (WSBS) on pages 93 to 109. https://doi.org/10.1007/978-3-319-95516-2_6

El-Demerdash MA, Hosni HA \& Al-Ashri N (1997). Distribution of the weed communities in the North-East Nile Delta, Egypt. Feddes Repertorium 108: 219-232. https://doi.org/10.1002/fedr.4921080311

El-Gabaly MM, Gewaifel IM, Hassan MN \& Rozanov BG (1969). Soil map and land resources of the United Arab Republic. Res. Bull. 22: 1-14. http://www.fao.org

El-Hadidi MN \& Kosinová J (1971). Studies on the weed flora of cultivated land in Egypt. 1. Preliminary survey. Mitteilungen Botanischen der Staatssammlung München 10: 354-367.

https://www.biodiversitylibrary.org/

Ellenberg H, Weber HE, Düll R, Wirth W, Werner W \& Paulien D (1992). Zeigerwerte von Pflanzen in Mitteleuropa. Scripta Geobotanica 18: 1-258. https://doi.org/10.1002/fedr.19931040323

Frick B and Thomas AG (1992). Weed surveys in different tillage systems in south western Ontario field crops. Can. J. Plant Sci. 72, 1337 - 1347. https://doi.org/10.4141/cjps92-166

Fried G, Norton RL \& Reboud X (2008). Environmental and management factors determining weed species composition and diversity in France. Agriculture, Ecosystems and Environment 128: 68-76. 
Retrieved from https://www.journals.elsevier.com/agriculture-ecosystems-and-environment/

Ghersa GM and Holt JS (1995). Using phenology prediction on weed management: a review. Weed Res. 35, 461 - 470. https://doi.org/10.1111/j.1365-3180.1995.tb01643.x

Gholinejad B , Farajollahi A and Pouzesh H (2012). Environmental factors affecting on distribution of plant communities in semiarid area (Case study: Kamyaran rangelands, Iran). Annals of Biological Research 3 (8):3990-3993. ISSN 0976-123, Retrieved from www.scholarsresearchlibrary.com

Gregorich EG, Carter MR, Angers DA, Monreal CM, Ellert BH (1994). Towards a minimum data set to assess soil organic matter quality in agricultural soils. Can. J. Soil Sci. 74, 367-385. https://doi.org/10.4141/cjss94-051

Hamblin AP, Hamblin J (1985). Root characteristics of some temperate legume species and varieties on deep, free-draining entisols. Australian Journal of Agricultural Research volume 36 issue 1 on page 63. https://doi.org/10.1071/ar9850063

Hammer, Ø., Harper, D.A.T., Ryan, P.D. 2001. PAST: Paleontological statistics software package for education and data analysis. Palaeontologia Electronica 4(1): 9pp. Retrieved from http://folk.uio.no/ohammer/past/

Harper DAT (1999). Numerical Palaeobiology. Computer-Based Modelling and Analysis of Fossils and their Distributions. $x+468$ pp. (ed.). Chichester, New York, Weinheim, Brisbane, Singapore, Toronto: John Wiley \& Sons. https://doi.org/10.1017/s0016756800334410

Hayami, Y and K Otsuka (1992): 'Beyond the Green Revolution: Agricultural Development Strategy into New Century' in Jock R Anderson (ed), Agricultural Technology: Policy Issues for the International Community, The World Bank, Washington, DC, US, pp 35. Retrieved from https://www.worldbank.org/ Hendricks WA, Robey KW (1936). "The Sampling Distribution of the Coefficient of Variation". The Annals of Mathematical Statistics. 7 (3): 129-32. https://doi.org/10.1214/aoms/1177732503

Hill MO \& Gauch HG (1980). Detrended correspondence analysis: an improved ordination technique. Vegetatio 42: 47-58. Retrieved from https://www.jstor.org/journal/vegetatio

Hill MO (1973). Diversity and evenness: a unifying notation and its consequences. Ecology. 54: 427-432. https://doi.org/10.2307/1934352

Holzner W (1978). Weed species and weed communities. Vegetatio38:13-20. https://doi.org/10.1007/bf00141295

Hoveizeh H (1997). Study of the vegetation cover and ecological characteristics in saline habitats of Hoor Shadegan. J. Res. Const. 34: 27-31. Retrieved from https://ascelibrary.org/journal/jcemd4 
Joint Research Center, European Soil Data Centre (ESDAC) (2017). Geological map of Egypt. https://esdac.jrc.ec.europa.eu

Kolar CS, Lodge DM (2001). Progress in invasion biology: predicting invaders. Trends in Ecology \& Evolution. 16 (4): 199-204. https://doi.org/10.1016/s0169-5347(01)02101-2

Krishnamoorthy K \& Meesook L (2013). "Improved tests for the equality of normal coefficients of variation". Computational Statistics. 29 (1-2): 215-232. doi:10.1007/s00180-013-0445-2

Lane DR, Coffin DP \& Lauenroth WK (1998). Effects of soil texture and precipitation on above-ground net primary productivity and vegetation structure across the Central Grassland region of the United States. Journal of Vegetation Science 9: 239-250. https://doi.org/10.2307/3237123

Le HouŽrou HN (1984). Rain use efficiency: a unifying concept in arid-land ecology. J. Arid Environ. 7: 213-214. Retrieved from https://www.journals.elsevier.com/journal-of-arid-environments/

Legendre, P. \& Legendre, L. (1998) Numerical Ecology. Amsterdam, , p. 853, the Netherlands: Elsevier. Published Aug 2000 in Ecological Modelling volume 132 issue 3 on pages 303 to 304 https://doi.org/10.1016/s0304-3800(00)00291-x

Lepš J \& Šmilauer P (2003). Multivariate Analysis of Ecological Data using CANOCO. International course on multivariate analysis, ISBN 0521891086, Cambridge University Press. regent.jcu.cz/maed

Letey $\mathrm{J}$ (1985). Irrigation uniformity as related to optimum crop production ? additional research is needed. Irrigation Science volume 6 issue 4. https://doi.org/10.1007/bf00262470

Lotz LAP, Groeneveld RMW, Habekotte B, and Oene H (1991). Reduction of growth and reproduction of Cyperus esculentus by specific crops. Weed Research 31:153-160. https://doi.org/10.1111/j.13653180.1991.tb01754.x

Magurran AE \& McCarthy BC (2004). Measuring Biological Diversity. Blackwell Publishing, Oxford, 256 p. https://doi.org/10.2307/4126959

Mahgoub AMMA (2017). Diversity and Biostatistics of the plant life in the Northwest of the Delta, Egypt. Retrieved from www.academia.edu., http://dx.doi.org/10.17632/4whz2tg553.1

Mahgoub AMMA (2019a). The impact of five environmental factors on species distribution and weed community structure in the coastal farmland and adjacent territories in the northwest delta region, Egypt. Heliyon Volume 5, Issue 4, e01441. https://doi.org/10.1016/j.heliyon.2019.e01441

Mahgoub AMMA (2019b). Comparative view for the impact of five eco factors on species distribution and weed community structure in Isthmus of Suez and adjoining farmland east Nile delta, Egypt. https://doi.org/10.1016/j.heliyon.2019.e02161 
Mashaly I, El-Said El Halawany; Gehan Omar (2002). Floristic features of Damietta area in the north east Nile Delta, Egypt. Taeckholmia, 22(1):101-114. doi: 10.21608/taec.2002.12429

Mashaly I, El-Shahaby $\mathrm{O}$ and El-Ameir Y (2010). Floristic Features of the canal bank habitats, Egypt. Journal of Environmental Sciences, Vol. 39, No. 4 : 483-501. Retrieved from https://www.journals.elsevier.com/journal-of-environmental-sciences/

Menalled FND, Gross KL, Hammond M (2001). Weed aboveground and seedbank community responses to agricultural management systems. Ecological Society of America, 11 (6), pp. 1586-1601. https://doi.org/10.1890/1051-0761(2001)011[1586:waascr]2.0.co;2

Ministry of Agriculture and Land Reclamation (MALR), Department of soil survey, Egypt, http://www.agregypt.gov.eg, Accessed September 2018.

Müller-Dombois D \& Ellenberg H (1974). Aims and Methods of Vegetation Analysis. New York: John Wiley \& Sons. ISBN: 0-471-62290-7. Retrieved from https://www.wiley.com/en-eg

Nesser C, Dille JA, Krishnan G, Mortensen DA, Rawlinson JT, Martin AR, Bills LB (2004). Weed SOFT: a weed management decision support system. Weed Science 52, 115-122. https://doi.org/10.1614/p2002154

Oksanen J, Blanchet FG, Kindt R, Legendre P, Minchin PR, O'Hara RB, Simpson GL, Solymos P, Stevens MH, Wagner H (2016). Végan : Community Ecology Package. R-Package Version 3.6 http://CRAN.Rproject.org / Package/ Végan. Retrieved from https://cran.r-

project.org/web/packages/vegan/index.html

Orlóci L (1978). Multivariate analysis in vegetation research. W. Junk BV, The Hague. 451 p. https://doi.org/10.1007/978-94-017-5608-2

Passioura JB (1991). Soil structure and plant growth. Soil Research, volume 29 issue 6 on page 717. https://doi.org/10.1071/sr9910717

Pearson K (1895) "Notes on regression and inheritance in the case of two parents," Proceedings of the Royal Society of London, 58: 240-242 https://doi.org/10.1098/rspl.1895.0041

Pearson K (1900). "On the criterion that a given system of deviations from the probable in the case of a correlated system of variables is such that it can be reasonably supposed to have arisen from random sampling" Philosophical Magazine. Series 5.50 (302): 157-175. doi:10.1080/14786440009463897

Pielou EC. (1975). Ecological Diversity. John Wiley and Sons., pp 165. https://doi.org/10.4319/lo.1977.22.1.0174b

Pinke G, Pál R and Botta-Dukát Z (2010). Effects of environmental factors on weed species composition of cereal and stubble fields in western Hungary. Cent. Eur. J. Biol., 5 (2), pp. 283-292. 
Press WH, Teukolsky SA, Vetterling WT \& Flannery BP (1992). Numerical Recipes in C. Cambridge University Press, Cambridge. https://doi.org/10.1017/s0263574700010675

Preston FW (1948). The Commonness, And Rarity, of Species. Ecology. 29 (3): on pages 254 to 283. https://doi.org/10.2307/1930989

Reichard SH \& Hamilton CW (1997). "Predicting invasions of woody plants introduced into North America". Conservation Biology. 11 (1): 193-203. doi:10.1046/j.1523-1739.1997. 95473.x

Rew LJ \& Cousens RD (2001). Spatial distribution of weeds in arable crops: are current sampling and analytical methods appropriate. Weed Research 41,1-18.

Reyniers M, Maertens K, Vrindts E \& De Baerdemaeker J (2006). Yield variability related to landscape properties of a loamy soil in central Belgium. Soil \& Tillage Research 88, 262-273.

https://doi.org/10.1016/j.still.2005.06.005

Robert PC (2002). Precision agriculture: a challenge for crop nutrition management. Plant and Soil 247, 143-149. https://doi.org/10.1007/978-94-017-2789-1_11

Ryabko BYa, Stognienko VS, Shokin Yul (2004). "A new test for randomness and its application to some cryptographic problems". Journal of Statistical Planning and Inference. 123 (2): 365376.doi:10.1016/s0378-3758(03) $00149-6$

Ryan MR, Smith RG, Mortensen DA, Teasdale JR, Curran WS, Seidel R \& Shumway DL (2009). Weed-crop competition relationships differ between organic and conventional cropping systems. Weed Research Society Weed Research 49, 572-580 DOI: 10.1111/j.1365-3180.2009. 00736.x

Said R (1962). The Geology of Egypt. Elsevier, New York, Science 140, pp. 41. DOl:

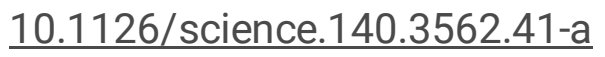

Sala OE., Parton WJ, Joyce LA \& Lauenroth WK (1988). Primary production of the central grassland region of the United States. Ecology 69: 40-45. https://doi.org/10.2307/1943158

Salonen J (1993). Weed infestation and factors affecting weed incidence in spring cereals in Finland - a multivariate approach. Agricultural Science in Finland 2: 525-536. https://doi.org/10.23986/afsci.72678

Shaltout K.H. \& Sharaf El-Din A. (1988). Habitat types and plant communities along transect in the Nile Delta region. Feddes Repertorium 99: 153-162. https://doi.org/10.1002/fedr.4910990317

Shaltout K.H., Sharaf El-Din A. \& El-Fahar R.A. (1992). Weed communities of the common crops in Nile Delta region. Flora 187: 329-339. https://doi.org/10.1016/s0367-2530(17)32240-5 
Shaltout KH, Hosni HA, El-Fahar RA and Ahmed DA (2015). Flora and vegetation of the different habitats of the western Mediterranean region of Egypt. Taeckholmia 35: 45-76.

https://doi.org/10.21608/taec.2015.12216

Shannon CE and Weaver W (1949). The Mathematical Theory of Communication. Urbana: University of Illinois Press. https://doi.org/10.5962/bhl.title.104652

Simpson EH (1949). Measurement of diversity. Nature, 163:688. https://doi.org/10.1038/163688a0

Sokal RR \& Rohlf FJ (1995). Biometry: The Principles and Practices of Statistics in Biological Research. Book, 3rd ed. Freeman, New York, NY, US. pp. 880 / 899, ISBN 10: 0716724111. Retrieved from https://bok.cc/book/

Streibig JC (1979). Numerical methods illustrating the phytosociology of crops in relation to weed flora. Journal of Applied Ecology 16: 577-587. https://doi.org/10.2307/2402532

Täckholm V (1974). Students' Flora of Egypt, 2nd ed. Cairo: Cairo University Press. 이: 14735955M. Retrieved from https://cu.edu.eg/

ter Braak CJF (1988c). CANOCO - a FORTRAN program for canonical community ordination by [partial] [detrended] [canonical] correspondence analysis, principal components analysis and redundancy analysis (version 2.1). Report LWA-88-02. Wageningen: Agricultural Mathematics Group. Retrieved from http://www.canoco5.com/

ter Braak CJF \& Prentice IC (1988). A theory of gradient analysis. Advances in Ecological Researches 18:271-317. https://doi.org/10.1016/S0065-2504(08)60183-X

ter Braak CJF (1990). Update Notes: CANOCO Version 3.1. Wageningen: Agricultural Mathematics Group. USA www.canoco.com.

The Plant List (2013). Version 1.1 Published on the Internet; www.theplantlist.org/ (accessed 1st January).

Thebaud C, Finzi AC, Affre L, Debussche M, Escarre J (1996). Assessing why two introduced Conyza differ in their ability to invade Mediterranean old fields. Ecology. 77 (3): 791-804.

https://doi.org/10.2307/2265502

Thomas AG, Frick BL (1993). Influence of tillage Systems on weed abundance in south western Ontario. Weed Technol., 7, pp. 699-705. https://doi.org/10.1017/S0890037X0003757X

Tichý L (2001). JUICE 4.0. Program for management, analysis and classification of ecological data. Software user's guide. Department of Botany, Masaryk University, Brno, CZ. Retrieved from https://www.sci.muni.cz/botany/juice/ 
Torun H \& Uygur N (2018). Relationship between weed populations and crop rotation systems. Türkiye VII. Bitki Koruma Kongresi (Uluslararası Katılımlı), 14-17 Kasım 2018, Muğla, Türkiye.

http://www.bitkikoruma2018.com

Tuomisto H (2010) A diversity of beta diversities: straightening up a concept gone awry. Part 1. Defining beta diversity as a function of alpha and gamma diversity. Ecography 33: 2-22. doi:10.1111/j.1600$\underline{0587.2009 .05880}$

Van den Wollenberg AL (1977). Redundancy analysis an alternative for canonical correlation analysis. Psychometrika volume 42 issue 2 on pages 207 to 219. https://doi.org/10.1007/bf02294050

Van Ittersum MK, Leffelaar PA, Van Keulen H, Kropff MJ, Bastiaans L \& Goudriaan J (2003). On approaches and applications of the Wageningen crop models. European Journal of Agronomy 18, 201234. https://doi.org/10.1016/s1161-0301(02)00106-5

Verberk W (2011). "Explaining General Patterns in Species Abundance and Distributions". Nature Education Knowledge. 3 (10): 38 Retrieved from https://www.nature.com/scitable/knowledge/library/

Voroney RP and Angers DA (1995). Analysis of the short-term effects of management on soil organic matter using the CENTURY model. In: Lal, R., et, al. (Eds.), Soil Management and Greenhouse Effect. Lewis Publishers, Boca Raton, FL, pp.113-120. https://doi.org/10.1201/9780203739310-10

Whittaker RH (1962). Classification of natural communities. The Botanical Review volume 28 issue 1 on pages 1 to 239 . https://doi.org/10.1007/bf02860872

Whittaker RH (1972). Evolution and measurement of species diversity. TAXON volume 21 issue 2-3 on pages 213 to $251 \mathrm{https}: / /$ doi.org/10.2307/1218190

Zelený D. (2019). Analysis of community ecology data in R, Variation partitioning (constrained ordination). David Zelený website, retrieved from https://www.davidzeleny.net/anadatr/doku.php/en:varpart.

Zhang JT, Xi Y and Li. J (2006). The relationships between environment and plant communities in the middle part of Taihang Mountain Range, North China. Community Ecol. 7: 155-163. https://doi.org/10.1556/comec.7.2006.2.3

Zimdahl RL (2004). Weed-Crop Competition: A Review, 2nd Edn. Book, Blackwell Publishing, Ames, IA, USA. DOI:10.1002/9780470290224

\section{Table}

Please see the supplementary files section to view the table. 


\section{Figures}

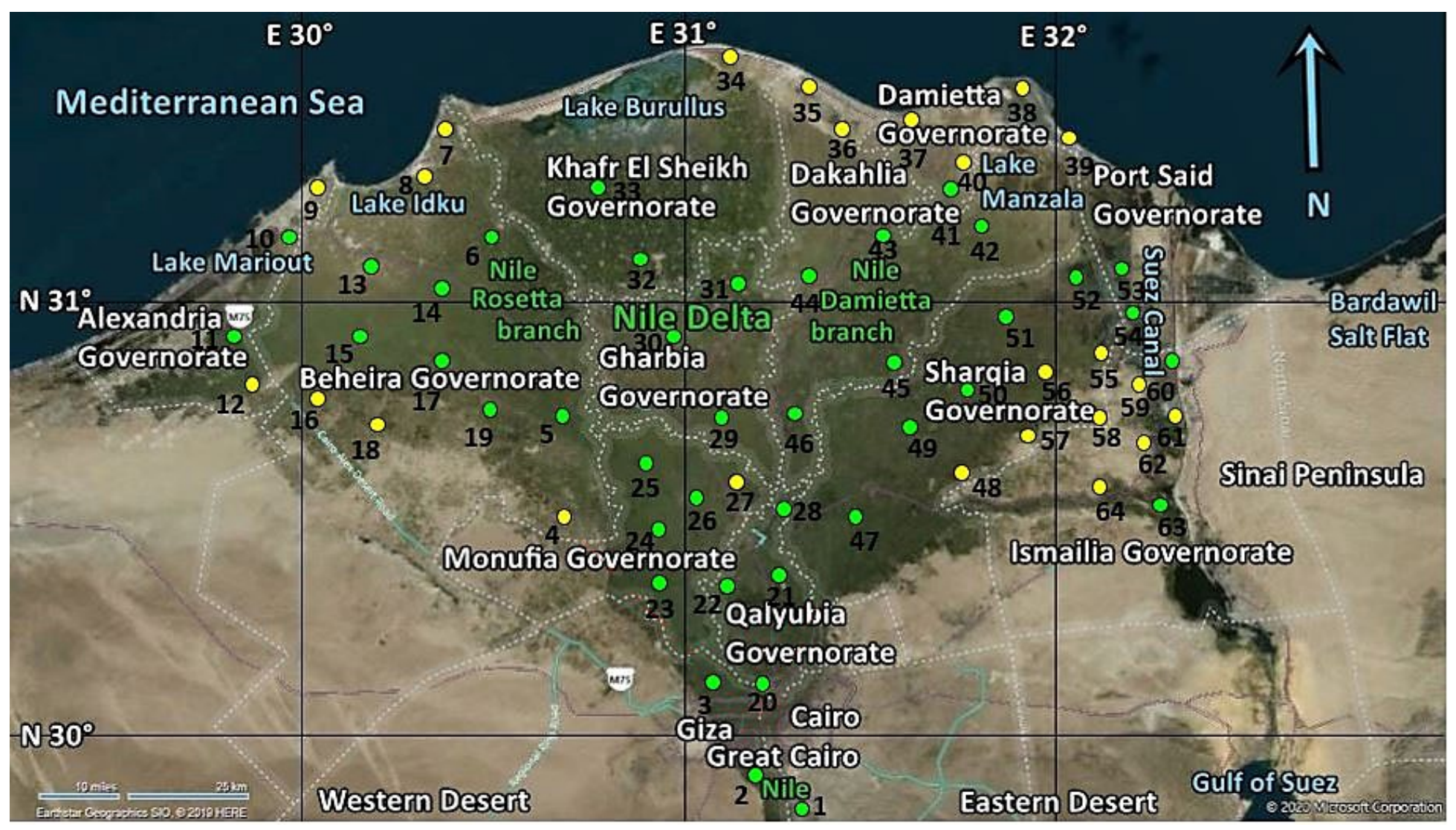

Figure 1

Location Map of the surveyed area. A total of 64 georeferenced sampling sites were surveyed in 12 governorates to represent 30 agronomic and horticultural crops cultivated in the different ecological habitats. Sampling sites characterized by "FGS" represented by green dots (40) while those characterized by "CGS" represented by yellow dots (24). "Map adapted from Bing Maps. Microsoft product screen shot(s) reprinted with permission from Microsoft Corporation. (C 2019-2020 Microsoft". 


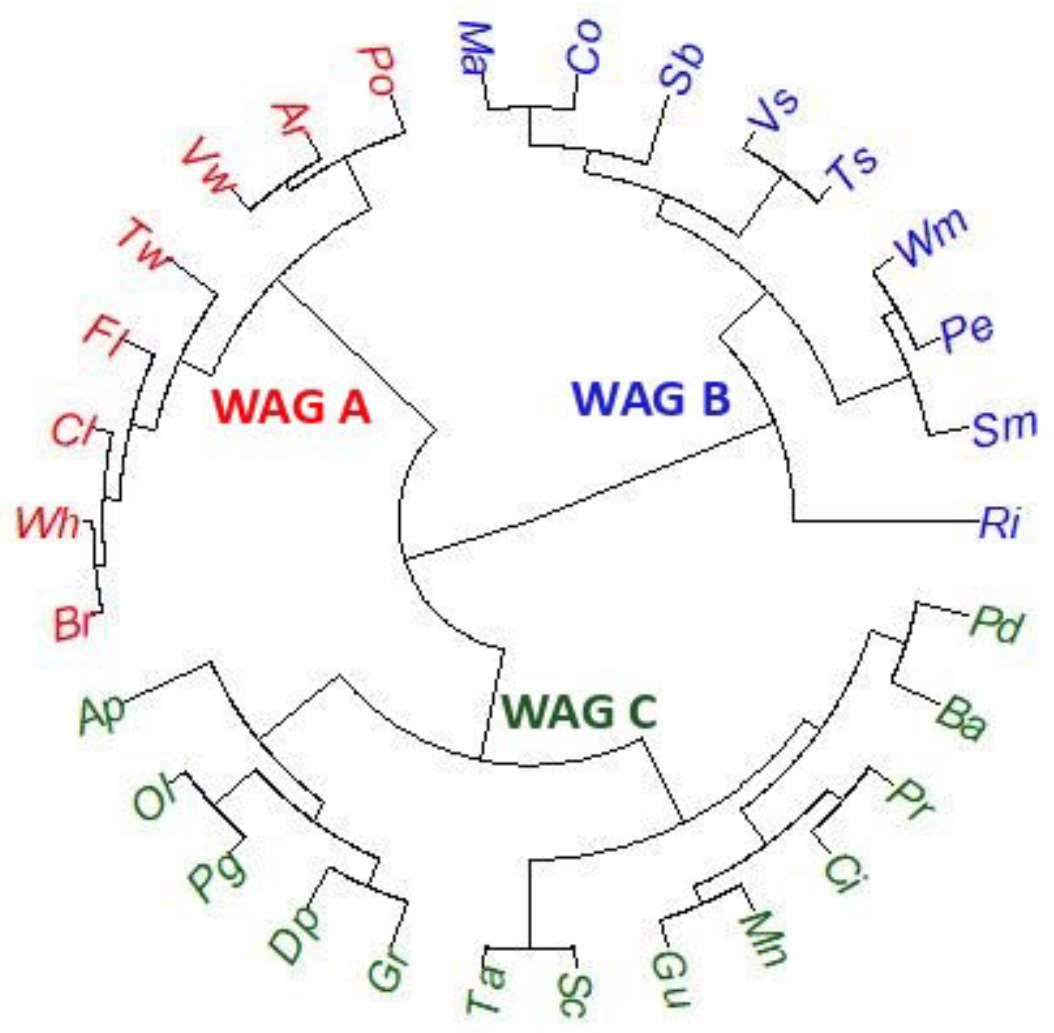

Figure 2

Fan-shaped dendrogram representing AHC for weed assemblages associated with 30 agroecosystems surveyed (for crop legend, refer to synoptic table, Appendix 1). 


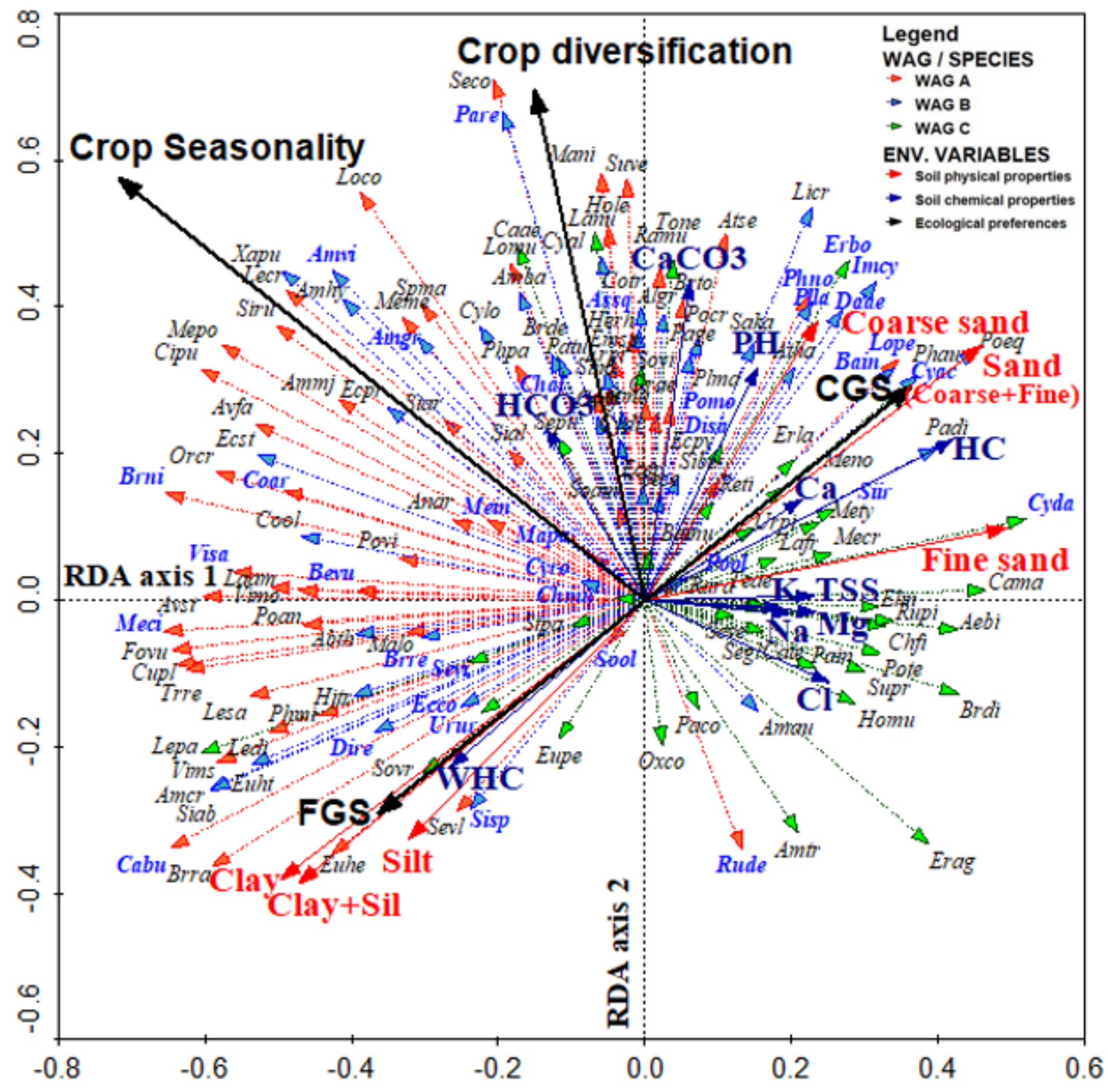

Figure 3

RDA correlation biplot (axis $1 \& 2$ ) displaying the preference of species with WAG (A-C) superimposed as response variables for environmental variables (ecological preferences and soil physical properties and soil chemical properties) as explanatory variables (for species codes refer to synoptic table, Appendix 1). 


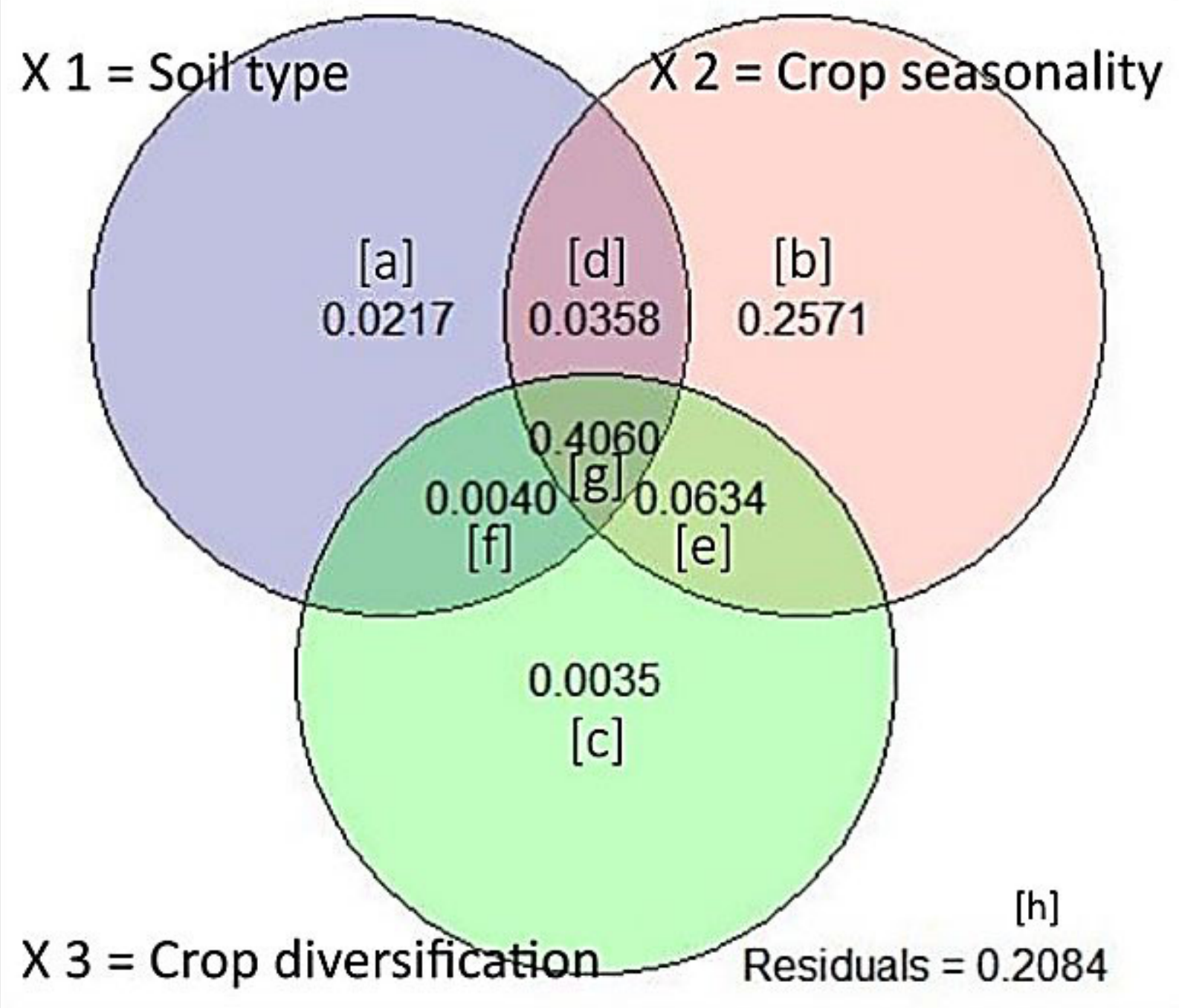

\section{Figure 4}

Venn's diagram, showing partition of the variation explained by the three ecological preferences (79.16\%). Adjusted R2 was used for comparison of the marginal and conditional effect of the explanatory variables and the individual fractions.

\section{Supplementary Files}

This is a list of supplementary files associated with this preprint. Click to download.

- Appendix1Synoptictable.xlsx

- Table1.xIsx 